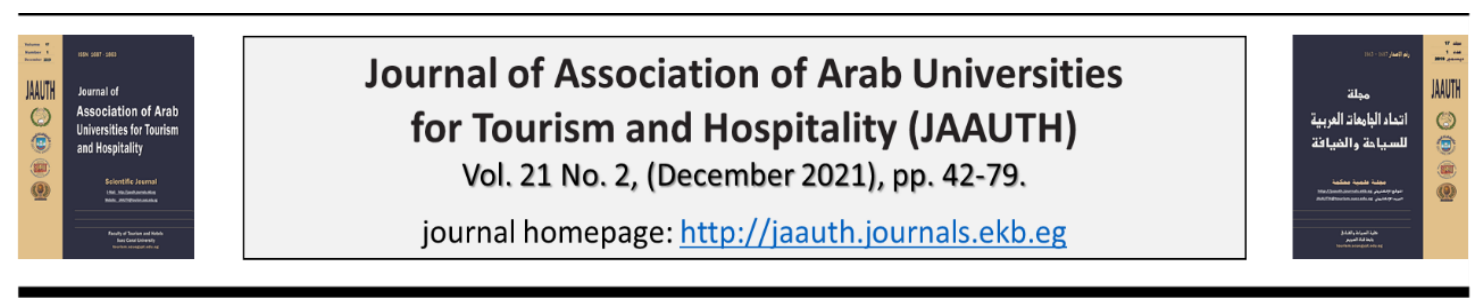

\title{
The Interplay of Motifs Reflecting the Doorkeeper's Duties Form and Function
}

\section{Rania Younes Merzeban}

Associate Professor - Tourist Guiding Department

Faculty of Tourism and Hotels, Alexandria University, Egypt

\section{ARTICLE INFO}

Keywords:

Doorkeeper; figured motifs; realism; gestures.

\section{(JAAUTH) \\ Vol. 21, No. 2, (December 2021), pp. 42-79.}

\section{ABSTRACT}

Doorkeepers form part of the workmen community about whom the information is occasional. The figured motifs of the doorkeepers hint at their role in securing a place efficiently. Though less informative small-scaled motifs may seem to be, they provide useful information regarding the lives of individuals. One of such motifs is the doorkeeper whose figure was not an ornamental motif; rather a functional one. Subject of the current research is defining, detecting and reassessing the status of doorkeepers in the ancient Egyptian society by means of the interpretation of the interplay of motifs in the scenes. In this respect the doorkeepers' gestures, attitudes and attributes are valuable sources of information. Unlike other workers and artisans, the doorkeeper's work was in the palace interiors and store rooms. The originality of the subject in the New Kingdom makes the doorkeeper motif a remarkable addition to the scene repertoire of daily life activities, this time within the palace. Interpreting the iconography and the interplay of motifs in the scenes enable a better understanding of the doorkeeper's role.

\section{Introduction}

Doorkeepers form part of the workmen community about whom the information is occasional. The figured motifs of the doorkeepers hint at their role in securing a place efficiently; a necessary procedure to allow persons to proceed through an area. Offices of doorkeepers $N^{2} w^{1}$ iry 3 and guardians s3wty, seem to have been closely related. ${ }^{4}$ According to Černy, a guard started his

\footnotetext{
${ }^{1} \mathrm{~Wb}$ I, 104, (3); 164, (17).

${ }^{2} \mathrm{~Wb}$ III, 418, (1) 'der Wächter'. The term is attested since the Middle Kingdom.

${ }^{3} \mathrm{~Wb}$ III, 418, (8).

4 Černy, J., A Community of workmen at Thebes in the Ramesside period, BdE 50, 3rd edition (Cairo, 2004), 158, 168; Goecke-Bauer, M., "Untersuchungen zu den 'Torwächtern' von Deir el Medine”, in: Jac. J. Janssen (ed.), Woodcutters, potters and doorkeepers. Service personnel of the Deir el-Medina workmen, EgUit 17 (Leiden, 2003), 143, 144.
} 
career as iry 3. $^{5}$ Doorkeepers were mentioned among the workmen community of the Deir el-Medineh personnel on ostraca and papyri. ${ }^{6}$

Although doorkeepers made their appearance in the models of $M k t-R^{\top}$ dated to the Middle Kingdom, they were only introduced in representations during the New Kingdom. They appeared as particular anonymous characters, never supposedly uttering any of the inscriptions. The tomb of Ini-iti.f at Thebes (TT 155) ${ }^{7}$ provides the only exceptional scene where part of the inscription is supposedly uttered by the doorkeeper.

Though less informative small-scaled motifs may seem to be, they provide useful information regarding the lives of individulas. One of such motifs is the doorkeeper whose figure was not an ornamental motif; rather a functional one. The doorkeeper's figure is typologically comparable to the small-scaled genre motifs complementing scene constituents. He appears to be a feature of the house that has been stimulated in particular during the Amarna period.

The gate is the most characteristic element associated to the doorkeeper in representational material. Whether opened ${ }^{8}$ or closed, ${ }^{9}$ the door leaf $\square$ could be that of a house, a city or a chapel, etc. ${ }^{10}$ In most cases there are no captions attached to the compositions. Yet, in a few others their attributes or the inscriptions related to passersby or other people represented in the scenes, help provide significant interpretations.

Subject of the current research is defining, detecting and reassessing the status of doorkeepers in the ancient Egyptian society by means of the interplay of motifs in the scenes. The study is merely limited to constitute and analyze the corpus of the iconographical representations of doorkeepers in the context of their work in everyday life while performing their tasks.

A thorough investigation proved the attestation of the following titles of doorkeepers: "doorkeepers of the doors of the sky" as in PT 1252 (P. 470) (P. 336)

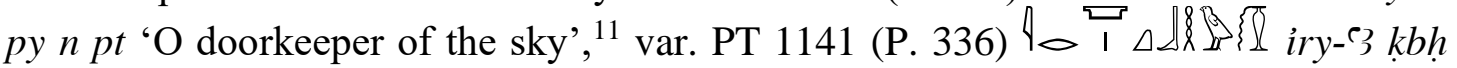
'doorkeeper of $k b h$ (i.e. the sky)', 12 "doorkeeper of the earth", 13 "doorkeeper of the

\footnotetext{
${ }^{5}$ Černy, A Community of workmen at Thebes in the Ramesside period, $149 \mathrm{ff}$.

6 Janssen, Jac. J., Village Varia: Ten Studies on the History and Administration of Deir-el-Medina, EgUit 11 (Leiden, 1997), 55.

7 Guglielmi, W., Reden, Rufe und Lieder auf altägyptischen Darstellungen der Landwirtschaft, Viehzucht, des Fisch- und Vogelfangs vom Mittleren Reich bis zur Spätzeit, TÄB 1 (Bonn, 1973$), 87$.

8 An example is shown in Davies, N. de G., The Rock tombs of El Amarna. Part 6: Tombs of Parennefer, Tutu and Ä̈, ASEg 18 (London, 1908), pl. 4, west wall.

${ }^{9}$ An example is shown in Davies, N. de G., The Rock tombs of El Amarna. Part 2: Tombs of Panehesy and Meryra II, ASEg 14 (London, 1905), pl. 13, east wall.

${ }^{10} \mathrm{~Wb}$ I, 164, (12)-(14).

${ }^{11} \mathrm{~Wb}$ I, 164, (18). See also PT 1252a (M. 535); PT 1252b (N. 1113-1114).

12 Also PT 1141a (M. 638).

${ }^{13} \mathrm{~Wb}$ I, 164, (19).
} 
Underworld" as in PT 411, 412 4 (T. 9) iry 3 $n \mathrm{Hr}$ 'doorkeeper of Horus', as well as BD chapter 125

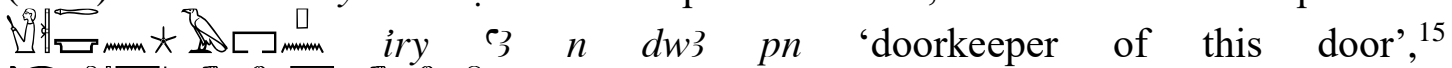
Ail

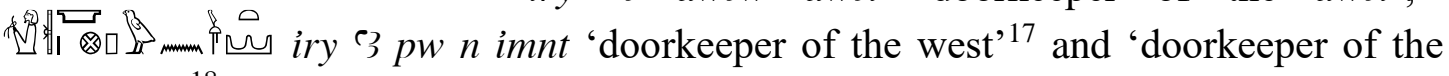
sun barks', ${ }^{18}$ etc. Yet, the religious context of the netherworld guards is outside the limits of the study, and therefore are not subject of the current study.

\section{The administrative title}

During the Old Kingdom doorkeepers were only mentioned in the Pyramid Texts. ${ }^{19}$ In the Middle Kingdom iry- 3 was an administrative title and appeared as The female rendering $4_{0}^{0}$ iryt- 3 appeared in the Pyramid Texts, spell $1440 \mathrm{e}, \mathrm{P}$ 651, M 750 as

The literal translation of the title $\mathrm{N}^{\mathrm{U}} \mathrm{\square}$, var. Berlin Wörterbuch "Pförtner", "Türhüter"22 (doorkeeper) having the main duty of guarding the door. The doorkeeper was closely related to the entrance and the gate; hence the typical inclusion of the door leaf in the title. The door in this sense defines the role of the person in charge, and possibly justifies his low ranked job. The function of "guarding a closed or open entrance leading to a place" was simply marked by the door leaf $\square$ or the strong arm $\backsim$. The title is composed of the nisbe iry and the substantive 3 . Cerny interpreted the title by reading iry-? 3 instead of $w n(w)^{23}$ 'open'. ${ }^{24}$

There are no sources recording the title from the Eighteenth dynasty; due to the very bad preservation state of the documents. ${ }^{25}$ The form $\square$ is obviously an abbreviated version of 411 [

${ }^{14}$ Also PT 1157 (P. 360); PT 1157a (N. 1073-1074); PT 1201a (M. 589); PT 1201b (N. 1194).

${ }^{15}$ Wb I, 164, (20). Also Naville, E., Das ägyptische Todtenbuch der XVIII. Bis XX. Dynastie (Berlin, 1886), Chapter 125, 38-39; also Chapter 52, 6-7; Chapter 141-143, 47; Chapter 147; Chapter 127 A, 1 3; Chapter 127 B, 10-13; Chapter 181, 1-5. Cf. Urk. IV, 64 (tomb of Inni).

${ }^{16}$ Naville, Das ägyptische Todtenbuch der XVIII. Bis XX. Dynastie, Chapter 127 B, 2-4; Chapter 127A, 1-3.

${ }^{17}$ Naville, Das ägyptische Todtenbuch der XVIII. Bis XX. Dynastie, Chapter 17, 81.

${ }^{18} \mathrm{~Wb}$ I, 164, (21).

${ }^{19}$ Jones, D., An Index of Ancient Egyptian Titles, Epithets and Phrases of the Old Kingdom I, BAR 866 (I) (Oxford, 2000), 312, 1140.

${ }^{20}$ Ward, W.A., Index of Egyptian Administrative and Religious Titles of the Middle Kingdom (Beirut, 1982), 61, nr. 500.

${ }^{21}$ Also PT 1440b (M. 752). Cf. PT 815a (M. 116); PT 815b (N. 54).

${ }^{22} \mathrm{~Wb}$ I, 104, (3); 164, (17); Anlex I, 36, 77.0371. See also Faulkner, R. O., A Concise Dictionary of Middle Egyptian (Oxford, 1988), 25; Goecke-Bauer, "Untersuchungen zu den 'Torwächtern' von Deir el Medine", 63, 64.

${ }^{23} \mathrm{~Wb}$ I, 311, (3).

${ }^{24}$ Černy, A Community of workmen at Thebes in the Ramesside period, 161.

${ }^{25}$ Goecke-Bauer, “Untersuchungen zu den 'Torwächtern' von Deir el Medine”, 75.

${ }^{26}$ Goecke-Bauer, "Untersuchungen zu den 'Torwächtern' von Deir el Medine”, 73-75. 
made its appearance in New Egyptian. ${ }^{27}$ It is noteworthy that the title 'chief doorkeeper' was attested in examples such as 'chief doorkeeper 'Imn-m-ib' in the tomb of 'Imn-m-ib at Thebes ${ }^{28}$ and

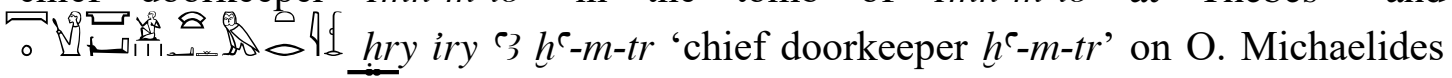
13, 6-7. ${ }^{29}$ The title $\_\Delta{ }^{30} s^{`} k n N$ was also used as designation of the temple's doorkeeper.

Deir el-Medineh documents (ostraca carrying lists of rations, ${ }^{31}$ private transactions, ${ }^{32}$ necropolis journals, ${ }^{33}$ and letters), include varied forms of the Egyptian administrative title iry '3, sometimes accompanied by doorkeepers' names. ${ }^{34}$ The doorkeepers' titles signalling their relationships with varied places reflect the diverse responsibilities they should have been taking. The door and the strong arm thus help defining the doorkeeper's activities. Since the Middle Kingdom the titles leave no doubt as to their attachment to temples, viziers' offices, specific halls, in addition to the storehouses as follows:

- 느는

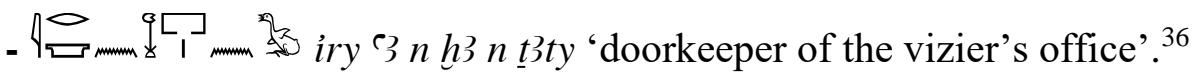

- 든 8 iry $3 n$ why 'doorkeeper of an audience-hall'. 37

- 는 iry '3 $n$ hnnrt 'doorkeeper of a prison'. 38

${ }^{27} \mathrm{~Wb}$ I, 165, (2).

${ }^{28}$ Champollion le Jeune, Monuments de l'Égypte et de la Nubie : notices descriptives conformes aux manuscrits autographes rédigés sur les lieux I (Paris, 1929), 851.

${ }^{29}$ Grandet, P., Catalogue des ostraca hiératiques non littéraires de Deîr el-Médinéh, Tome IX. Nos 831-1000, DFIFAO 41 (Cairo, 2003), 79; Černy, A Community of workmen at Thebes in the Ramesside period, 164-165.

${ }^{30}$ AnLex III, 243, 79.2455 "l'introducteur du dieu N", comme désignation du portier d'un temple. See Ramond, P., "Un socle pour une statuette de Thot", JEA 65 (1979), 170 n. (e).

${ }^{31}$ Among the lists of rations including the doorkeeper: O. Cairo 25608 rto, O. DeM 379, O. DeM 638 rto, O. DeM 376, O. DeM 149, O. DeM 381, O. DeM 735.

${ }^{32}$ O. Colin Campbell 23, I, O. Turin 57150, O. DeM 779, O. DeM 410, O. Cairo 25604, O. Černy 15, vso.

${ }^{33}$ O. DeM 34, O. DeM 427, O. DeM 604, pTurin Cat. 1891, vso 9, Giornale 17-A: dated by Gutgesell, M., Die Datierung der Ostraka und Papyri aus Deir el-Medineh und ihre ökonomische Interpretation. Teil I. Die 20. Dynastie, HÄB 18-19 (Hildesheim, 1983), 141.

${ }^{34}$ Goecke-Bauer, "Untersuchungen zu den 'Torwächtern' von Deir el Medine”, 65-73.

${ }^{35}$ Ward, Index of Egyptian Administrative and Religious Titles of the Middle Kingdom, 62, 502; Hannig, R., Ägyptisches Wörterbuch II: Mittleres Reich und Zweite Zwischenzeit I, Kulturgeschichte der Antiken Welt 112 (Mainz am Rhein, 2006), 338, \{48807\}. Stela Frorence 8063 for example bears a designation of $\square$ iry 3 n pr-Imn 'doorkeeper of the temple of Amon'. To be also compared with the Middle Kingdom stela BM 1016, and the New Kingdom stela Turin 101 bearing the title $411 \mathrm{~V} 2$.

${ }^{36}$ Ward, Index of Egyptian Administrative and Religious Titles of the Middle Kingdom, 62, 503; Hannig, Ägyptisches Wörterbuch II: Mittleres Reich und Zweite Zwischenzeit I, 338, \{3090\}.

${ }^{37}$ Ward, Index of Egyptian Administrative and Religious Titles of the Middle Kingdom, 62, 501. 


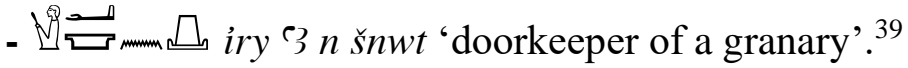

The following inscriptions recorded on statues include examples attested of the title:

Inscription on the statue of 'In hr nht (Avignon Inv. 35):

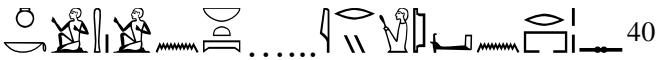

ink hm n nbt pt ...... iry 3 n r-pr.s

I am the servant of the mistress of the sky, ......, the doorkeeper of her temple (i.e. temple of $M h y t$ ).

Inscription on the statue of $R^{\mathrm{e}}-\mathrm{ms}$ :

Oी

ink hm n nbt pt iry 3 n pr.s

I am the servant of the mistress of the sky, the doorkeeper of her temple.

\section{Corpus Description}

The doorkeeper's motif appeared in three dimensional representations in the Middle Kingdom models of $M k t-R^{\Upsilon}$. Yet, attestations of figured doorkeepers was only attested in tomb scenes during the New Kingdom. In trying to study the doorkeepers' images, we are dependent on tomb scenes. Rather than to merely focus on the various types of doorkeepers' attitudes, suggestions and remarks will be presented on how related representations reflect their work duties. Their names were nevertheless never mentioned in such representations.

Most characteristic is the absence of any accompanying titles in the scenes, although doorkeepers' titles were mentioned on stelae and in other sources such as ostraca and papyri. Identifying the doorkeeper therefore manifests a problem, though not an impossible task. The examples show variations in gestures, poses and attitudes. The motif typologically reflects a low social position, certainly denoting exceptional unconventional representations. Several different attitudes were detected and identified (table 1, 2,3). Sufficient evidence is therefore available to illustrate indices and aspects of their duties.

It is noteworthy that doorkeepers at the palace interiors and in storerooms are to be distinguished from doorkeepers of temples and palaces; the later enjoyed a high ranked position. The titles provide additional information in trying to distinguish doorkeepers' identities.

${ }^{38}$ Ward, Index of Egyptian Administrative and Religious Titles of the Middle Kingdom, 62, 504; Hannig, Ägyptisches Wörterbuch II: Mittleres Reich und Zweite Zwischenzeit I, 338, \{48858\}.

${ }^{39}$ Ward, Index of Egyptian Administrative and Religious Titles of the Middle Kingdom, 62, 505; Hannig, Ägyptisches Wörterbuch II: Mittleres Reich und Zweite Zwischenzeit I, 338, \{48718\}.

${ }^{40}$ Linköping 189: 5000 år Egypt. konst (Nationalmuseum Stockholm), pl. 26, nr. 98; Clère, J. J., "Deux statues 'gardiennes de porte", JEA 54 (1968), 144.

${ }^{41}$ Clère, "Deux statues 'gardiennes de porte", 144. 


\section{The doorkeeper: an appealing motif}

The doorkeeper is not one of the most recurrent figures in ancient Egyptian figurative documents. The motif is one of the unexpected newly introduced details to New Kingdom compositions. In this approach to study the motif, it appeared that it typically reflects glimpses of realistic art. The details studied highlight the role of the doorkeeper, and the artistic conventions adopted in picturing the motif. Although the theme proved to have existed since the Middle Kingdom, It is noteworthy that it was only introduced in the scene repertoire during the Amarna period. It was repeatedly attested several times in the same tombs. This suggests a tendency towards recreating and including it frequently, especially in palatial contexts. It might therefore be suggested that the motif became an appealing subject to the artists.

The scenes show only male guards. However, Kanawati highlighted the role of a female guard who bore the title hnty-šs. The position of a female guard was rarely acquainted and may have served in the most intimate parts of the royal Harem. ${ }^{42}$ Guards were never named in scenes; yet some of their names were encountered in ostraca and in letters. Nineteen iryw- 3 were known by names from the time of Ramsses II till Ramsses XI in ostraca and papyri. ${ }^{43}$

Far from conventional representations, the doorkeeper's figure seems to have been a light-hearted element, shown bare feet, unattended and unarmed. His gestures, attitudes and attributes are valuable sources of information. The postures of the represented doorkeepers, in addition to their attributes highlight low ranked position. The motif was pictured several times standing nearby, behind or in front of the doorway, sometimes engaged in cleaning the floor. His gestures show him often alternating between squatting at the door, sitting on a cushion, or as a crouching figure with his face leaned on his hand in a sleepy attitude. He was also occasionally shown verifying visitors' identity before allowing them access.

It is noteworthy that representations of doorkeepers showed them small in scale and proportion in comparison to the major figures in the scenes. The canon of proportions reveal the small or miniature size of the doorkeepers in comparison to the tomb owner's heroic size, and the subordinates' relatively smaller size.

\section{The context}

The occasions and contexts in which doorkeepers appear effectively complement the information given in the texts recorded on ostraca and papyri. The newly introduced motifs were common in Amarna period iconography, and these details significantly share several features. Most, yet not all of the related iconography, derive from palatial contexts, where interior spaces were indicated by walls and columns. ${ }^{44}$ Stylistic parallels of the doorkeeper's motif appear during the Eighteenth and the Nineteenth Dynasties, with variations in poses and attitudes.

\footnotetext{
${ }^{42}$ Kanawati, N., "A Female Guard Buried in the Teti Cemetery”, BACE 12 (2001), 66, 67.

${ }^{43}$ Goecke-Bauer, "Untersuchungen zu den 'Torwächtern' von Deir el Medine”, 152.

${ }^{44}$ Examples are shown in Davies, The Rock Tombs of El Amarna. Part 3, pl. XIII, west wall, palace interiors; Davies, The Rock tombs of El Amarna. Part 6, pl. 17, west wall, south side.
} 
The restricted access to certain areas was secured by the presence of the doorkeeper. Such areas could be private parts of a house, harem residence in the royal palace, storage areas, etc. Doorways expectedly were to be separating commonplaces from private areas where people were barred from entering.

The contexts where doorkeepers were figured appeared to be as follows:

- Palatial iconography

- Non-palatial iconography

- $\quad$ Store rooms

The number of the doorkeepers shown iconographically was generally one, and only in some cases two, in front of each doorway. Some palace life scenes pictured in the tomb of 'Iy at Amarna (no. 25) show male guards sitting or standing outside. ${ }^{45}$ In other contexts concerning the doorkeepers of the tombs, the texts mention that they were two or more, ${ }^{46}$ and their number seems to have been varying according to the needs. ${ }^{47}$ The royal tomb $p_{3} h r$ was guarded even when its entrance was sealed or closed, and when no work was going on. ${ }^{48}$

The doorkeeper's main charge should have been guarding the door and what relates to it; i.e. inspecting the identity of entering visitors. Other duties such as delivering supplies to the workmen seem to have been temporary. ${ }^{49}$ The duties of the iry ' 3 at Deir el-Medineh included deliveries of grain rations, provisions, vegetables and wood. ${ }^{50}$ O. Cairo 25611 recorded that the doorkeeper $h^{\prime}-m$-wzst had the duty of receiving and registering deliveries to the workmen. ${ }^{51}$ O. DeM 726 [inv. $1629+$ 1411], dated to the first year of the reign of Ramsses IV, recorded deliveries received by two doorkeepers. ${ }^{52}$ The doorkeeper's duties may have also included transmitting

${ }^{45}$ Davies, The Rock tombs of El Amarna. Part 6, pl. 28; B. Kemp, The City of Akhenaton and Nefertiti: Amarna and its people (Cairo, 2012), 144, fig. 4.18.

${ }^{46}$ Černy, A Community of workmen at Thebes in the Ramesside period, 162-164, 167; Valbelle, D., Les ouvriers de la tombe : Deir El-Médineh à l'époque ramesside, BdE 96 (Cairo, 1985), 127 (e.g. pTurin Cat. 1880 points to the multiple tasks assigned to doorkeepers. While two of them seem to have been assigned to guard the tomb, others were in charge of the provisions).

${ }^{47}$ Ventura, R., Living in a city of the dead: A selection of topographical and administrative terms in the documents of the Theban necropolis, OBO 69 (Freiburg, 1986), 112.

${ }^{48}$ Ventura, Living in a city of the dead, 88; Massart, A., "The Egyptian Geneva Papyrus MAH 15274", MDAIK 15 (1957), 182 n. 1.

${ }^{49}$ Ventura, Living in a city of the dead, 111, n. 31. Helck, W., "Türhüter", in W. Helck and E. Otto (eds.), $L \ddot{A}$ VI (Wiesbaden, 1986), 788.

${ }^{50}$ Goecke-Bauer, "Untersuchungen zu den 'Torwächtern' von Deir el Medine”, 94, 138; Gutgesell, Die Datierung der Ostraka und Papyri aus Deir el-Medineh und ihre ökonomische Interpretation I, 95, 105, 106; Janssen, Jac. J., Commodity prices from the Pamesside Period: An economic study of the village of necropolis workmen at Thebes (Leiden, 1975), 151-153.

${ }^{51}$ Janssen, Jac. J., "Two personalities", in R. J. Demarée and Jac. J. Janssen (eds.), Gleanings from Deir El-Medîna, EgUit 1 (Leiden, 1982), 117; Janssen, Commodity prices from the Pamesside Period, 20.

${ }^{52}$ Grandet, P., Catalogue hiératiques non littéraires de Deîr el-Médînéh, Tome VIII, $\mathrm{n}^{\text {os }}$ 706-830, DFIFAO 39 (Cairo, 2000), 27, 129. 
news and letters. ${ }^{53}$ According to O. Černy 17, the iryw ' 3 worked in shifts including a night watch. ${ }^{54}$ Besides, in O. Berlin 10663, 3, supposedly originally from Deir elMedineh, dated to year 28 of Ramsses III, iryw- 3 acted as letter carriers. ${ }^{55}$

\section{Gestures and attributes of doorkeepers}

Gestures of doorkeepers were classified into the following three categories as attested in the representations:

1. Sitting down/ crouching

2. Standing in front of, beside or behind the door

3. Cleaning the floor

\section{1 - Sitting down/ crouching}

The earliest representations of doorkeepers were three dimensional in the stable, granary, brewery and bakery models of the Eleventh Dynasty tomb of $M k t-R^{c}$ at Thebes. ${ }^{56}$ Scenes depicting doorkeepers sitting down or crouching were attested in the tombs of $H w y 3{ }^{57}{ }^{5} y^{58}$ and $T w t w w^{59}$ at Amarna. These represent variations in the poses attested.

Table 1 - The doorkeeper sitting down/ crouching

\begin{tabular}{|c|c|c|c|c|}
\hline $\begin{array}{c}\text { Tomb owner/ } \\
\text { Tomb } \\
\text { location }\end{array}$ & Figures (details) & Description & Attributes & Reference \\
\hline $\begin{array}{l}M k t-R^{r} \\
\text { Thebes }\end{array}$ & & $\begin{array}{l}\text { crouching nearby } \\
\text { the door } \\
\text { (stable) }\end{array}$ & stick & $\begin{array}{l}\text { Winlock, } \\
\text { Models of } \\
\text { Daily Life, pl. } \\
17 .\end{array}$ \\
\hline $\begin{array}{l}M k t-R^{r} \\
\text { Thebes }\end{array}$ & & $\begin{array}{l}\text { crouching nearby } \\
\text { the door } \\
\text { (granary) }\end{array}$ & stick & $\begin{array}{l}\text { Winlock, } \\
\text { Models of } \\
\text { Daily Life, pl. } \\
20 .\end{array}$ \\
\hline & & & & Continued \\
\hline
\end{tabular}

${ }^{53}$ Gutgesell, Die Datierung der Ostraka und Papyri aus Deir el-Medineh und ihre ökonomische Interpretation. Teil I. Die 20. Dynastie, $98 \mathrm{ff}$.

${ }^{54}$ Gutgesell, Die Datierung der Ostraka und Papyri aus Deir el-Medineh und ihre ökonomische Interpretation. Teil I. Die 20. Dynastie, 127, 128.

${ }^{55}$ Helck, "Türhüter", 788.

${ }^{56}$ Winlock, H. E., Models of Daily Life in Ancient Egypt from the Tomb of Meket-Rē $\bar{e}^{\varsigma}$ at Thebes (New York, 1955), pls. 17, 22, 25.

${ }^{57}$ Davies, N. de G., The Rock Tombs of El Amarna. Part 3: The Tombs of Huya and Ahmes, ASEg 15 (London, 1905), pl. 13.

${ }^{58}$ Davies, N. de G., The Rock tombs of El Amarna. Part 6: Tombs of Parennefer, Tutu and Ä̈, ASEg 18 (London, 1908), pl. 28, north wall, doorway, left side.

${ }^{59}$ Davies, The Rock tombs of El Amarna. Part 6, pl. 17, west wall, south side. 


\begin{tabular}{|c|c|c|c|c|}
\hline $\begin{array}{l}M k t-R^{r} \\
\text { Thebes }\end{array}$ & & $\begin{array}{l}\text { crouching nearby } \\
\text { the door } \\
\text { (brewery and } \\
\text { bakery) }\end{array}$ & stick & $\begin{array}{l}\text { Winlock, } \\
\text { Models of } \\
\text { Daily Life, pl. } \\
22 .\end{array}$ \\
\hline $\begin{array}{c}H w y 3 \\
\text { El-Ämarna }\end{array}$ & & $\begin{array}{l}\text { sitting down in } \\
\text { front of the door, } \\
\text { seemingly sleepy } \\
\text { (palatial context) }\end{array}$ & $\begin{array}{l}\text { none } \\
\text { apparent }\end{array}$ & $\begin{array}{l}\text { Davies, The } \\
\text { Rock Tombs } \\
\text { of } \quad \text { El } \\
\text { Amarna 3, pl. } \\
\text { 13. }\end{array}$ \\
\hline $\begin{array}{c}\text { Ty } \\
\text { El-Amarna }\end{array}$ & & $\begin{array}{l}\text { sitting on a } \\
\text { cushion, while } \\
\text { eating in front of } \\
\text { the door } \\
\text { (harem, palatial } \\
\text { context) }\end{array}$ & $\begin{array}{l}\text { none } \\
\text { apparent }\end{array}$ & $\begin{array}{l}\text { Davies, The } \\
\text { Rock tombs } \\
\text { of } \quad \text { El } \\
\text { Amarna } 6, \text { pl. } \\
28, \quad \text { north } \\
\text { wall, } \\
\text { doorway. }\end{array}$ \\
\hline $\begin{array}{c}\text { Ty } \\
\text { El-Amarna }\end{array}$ & & $\begin{array}{l}\text { crouching in } \\
\text { front of the door } \\
\text { on a cushion, } \\
\text { with head leaned } \\
\text { on his arms. } \\
\text { (harem, palatial } \\
\text { context) }\end{array}$ & $\begin{array}{l}\text { none } \\
\text { apparent }\end{array}$ & $\begin{array}{l}\text { Davies, The } \\
\text { Rock tombs } \\
\text { of } \quad \text { El } \\
\text { Amarna } 6, \mathrm{pl} . \\
28, \quad \text { north } \\
\text { wall, } \\
\text { doorway. }\end{array}$ \\
\hline $\begin{array}{c}\text { Ty } \\
\text { El-Amarna }\end{array}$ & & $\begin{array}{l}\text { sitting on a } \\
\text { cushion in front } \\
\text { of the door, } \\
\text { while holding a } \\
\text { brush (harem, } \\
\text { palatial context) }\end{array}$ & $\begin{array}{l}\text { brush for } \\
\text { sweeping the } \\
\text { floor }\end{array}$ & $\begin{array}{lr}\text { Davies, } & \text { The } \\
\text { Rock tombs } \\
\text { of } r \\
\text { Amarna } 6, \text { pl. } \\
28, \quad \text { north } \\
\text { wall, reft } \\
\text { side. }\end{array}$ \\
\hline $\begin{array}{c}\text { Twtw } \\
\text { El-Amarna }\end{array}$ & & $\begin{array}{l}\text { sitting on a } \\
\text { cushion in front } \\
\text { of the door } \\
\text { (palatial context) }\end{array}$ & $\begin{array}{l}\text { none } \\
\text { apparent }\end{array}$ & $\begin{array}{l}\text { Davies, The } \\
\text { Rock tombs of } \\
\text { El Amarna } 6 \text {, } \\
\text { pl. 17, west } \\
\text { wall, south } \\
\text { side. }\end{array}$ \\
\hline $\begin{array}{c}\text { Twtw } \\
\text { El-Amarna }\end{array}$ & & $\begin{array}{l}\text { sitting on a } \\
\text { cushion in front } \\
\text { of the door } \\
\text { (palatial context) }\end{array}$ & $\begin{array}{l}\text { none } \\
\text { apparent }\end{array}$ & $\begin{array}{l}\text { Davies, The } \\
\text { Rock tombs } \\
\text { of El } \\
\text { Amarna } 6, \text { pl. } \\
\text { 17, west wall, } \\
\text { south side. }\end{array}$ \\
\hline & & & & Continued \\
\hline
\end{tabular}




\begin{tabular}{|l|l|l|}
\hline $\begin{array}{l}\text { Ini iti.f } \\
\text { Thebes }\end{array}$ & $\begin{array}{l}\text { crouching behind } \\
\text { the door with his } \\
\text { head leaned on } \\
\text { his hand } \\
\text { (temporary } \\
\text { storage) }\end{array}$ & $\begin{array}{l}\text { Säve- } \\
\text { apparent } \\
\text { Söderbergh, } \\
\text { Four } \\
\text { eighteenth } \\
\text { Dynasty } \\
\text { tombs, pl. 15, } \\
\text { hall, right } \\
\text { back wall. }\end{array}$ \\
\hline
\end{tabular}

\section{2 - Standing in front of, beside or behind the door}

The study of the doorkeepers' figures allow to conclude that the standing posture in front of the door was the most eminent. This attitude was the most attested, probably as it reflects his characteristic job (e.g. tombs of Mry $R^{\mathrm{e}}{ }^{60} P 3$ nhsy ${ }^{61}$ Mry $R^{\complement} \mathrm{II},{ }^{62}$ $M h w,{ }^{63} P 3 r n n f r,{ }^{64} T_{w t w}{ }^{65}$ at Amarna and $N f r h t p^{66}$ at Thebes). In context, the figures related to this posture alternate between palatial contexts and store rooms.

Table 2 - The doorkeeper standing in front of, beside or behind the door

\begin{tabular}{|c|c|c|c|c|}
\hline $\begin{array}{c}\text { Tomb owner/ } \\
\text { Tomb } \\
\text { location }\end{array}$ & $\begin{array}{l}\text { Figures } \\
\text { (details) }\end{array}$ & Description & Attributes & Reference \\
\hline $\begin{array}{c}M r y R^{e} \\
\text { El-Amarna }\end{array}$ & & $\begin{array}{l}\text { standing in } \\
\text { front of the } \\
\text { door. } \\
\text { (palatial } \\
\text { context) }\end{array}$ & unclear & $\begin{array}{l}\text { Davies, The } \\
\text { Rock tombs of } \\
\text { El Amarna 1, } \\
\text { pl. 18, east } \\
\text { wall, lower } \\
\text { half. }\end{array}$ \\
\hline $\begin{array}{c}M r y R^{C} \\
\text { El-Amarna }\end{array}$ & & $\begin{array}{l}\text { reclining in } \\
\text { front of the } \\
\text { door. } \\
\text { (palatial } \\
\text { context) }\end{array}$ & unclear & $\begin{array}{l}\text { Davies, The } \\
\text { Rock tombs of } \\
\text { El Amarna } 1 \text {, } \\
\text { pl. 18, east } \\
\text { wall, lower } \\
\text { half. }\end{array}$ \\
\hline $\begin{array}{c}\text { P3 nhsy } \\
\text { El-Amarna }\end{array}$ & 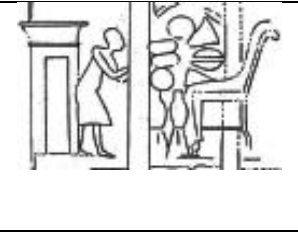 & $\begin{array}{l}\text { standing in } \\
\text { front of the } \\
\text { door. } \\
\text { (palatial } \\
\text { context) }\end{array}$ & unclear & $\begin{array}{l}\text { The Rock } \\
\text { tombs of El } \\
\text { Amarna 2, pl. } \\
\text { 13, east wall. }\end{array}$ \\
\hline & & & & Continued \\
\hline
\end{tabular}

\footnotetext{
${ }^{60}$ Davies, The Rock tombs of El Amarna. Part 1, pl. 18, pillared hall, west wall.

${ }^{61}$ Davies, The Rock tombs of El Amarna. Part 2, pl. 13, east wall.

${ }^{62}$ Davies, The Rock tombs of El Amarna. Part 2, pl. 36, south wall, east side.

${ }^{63}$ Davies, N. de G., The Rock Tombs of El Amarna. Part 4: The Tombs of Penthu, Mahu, and others, ASEg 16 (London, 1906), pl. 25, south end wall.

${ }^{64}$ Davies, The Rock tombs of El Amarna. Part 6, pl. 4, west wall.

${ }^{65}$ Davies, The Rock tombs of El Amarna. Part 6, pl. 17, 20 west wall, south side.

${ }^{66}$ Davies, N. de G., The tomb of Nefer-hotep at Thebes, Volume I, MMAEE 9 (New York, 1933), pl. $14,16,18$.
} 


\begin{tabular}{|c|c|c|c|c|}
\hline $\begin{array}{c}\text { Mry } R^{\mathrm{C}} \text { II } \\
\text { El-Amarna }\end{array}$ & & $\begin{array}{l}\text { standing while } \\
\text { leaning with } \\
\text { one leg against } \\
\text { the door at his } \\
\text { back. } \\
\text { (palatial } \\
\text { context) }\end{array}$ & $\begin{array}{l}\text { holding } \\
\text { something } \\
\text { unclear in one } \\
\text { hand, and } \\
\text { waving with } \\
\text { the other hand } \\
\text { while chatting } \\
\text { with someone. }\end{array}$ & $\begin{array}{l}\text { The Rock } \\
\text { tombs of El } \\
\text { Amarna 2, pl. } \\
\text { 36, south } \\
\text { wall, east side. }\end{array}$ \\
\hline $\begin{array}{c}M h w w \\
\text { El-Amarna }\end{array}$ & 14 & $\begin{array}{l}\text { standing in } \\
\text { front of the } \\
\text { door. } \\
\text { (store rooms) }\end{array}$ & stick & $\begin{array}{l}\text { Davies, The } \\
\text { Rock Tombs } \\
\text { of } r \text { El } \\
\text { Amarna 4, pl. } \\
\text { 25, south end } \\
\text { wall. }\end{array}$ \\
\hline $\begin{array}{c}\text { P3 rn nfr } \\
\text { El-Amarna }\end{array}$ & & $\begin{array}{l}\text { registering } \\
\text { articles brought } \\
\text { by a file of } \\
\text { servants } \\
\text { heading to the } \\
\text { stores. } \\
\text { (store rooms) }\end{array}$ & palette & $\begin{array}{l}\text { Davies, The } \\
\text { Rock tombs of } \\
\text { El Amarna } 6 \text {, } \\
\text { pl. 4, west } \\
\text { wall. }\end{array}$ \\
\hline $\begin{array}{c}\text { P3 rn nfr } \\
\text { El-Amarna }\end{array}$ & & $\begin{array}{l}\text { two guardians } \\
\text { keeping the } \\
\text { doorway } \\
\text { through which } \\
\text { servants } \\
\text { carrying baskets } \\
\text { and jars defile. } \\
\text { (store rooms) }\end{array}$ & $\begin{array}{l}\text { stick } \\
\text { brush (?) } \\
\text { palette (?) }\end{array}$ & $\begin{array}{l}\text { Davies, The } \\
\text { Rock tombs of } \\
\text { El Amarna 6, } \\
\text { pl. 4, west } \\
\text { wall. }\end{array}$ \\
\hline $\begin{array}{c}\text { Twtw } \\
\text { El-Amarna }\end{array}$ & & $\begin{array}{l}\text { standing while } \\
\text { leaning with } \\
\text { one leg against } \\
\text { the door at his } \\
\text { back. } \\
\text { (palatial } \\
\text { context) }\end{array}$ & $\begin{array}{l}\text { holding } \\
\text { something } \\
\text { unclear in one } \\
\text { hand, while } \\
\text { chatting with } \\
\text { someone. }\end{array}$ & $\begin{array}{l}\text { Davies, The } \\
\text { Rock tombs of } \\
\text { El Amarna 6, } \\
\text { pl. 17, west } \\
\text { wall, south } \\
\text { side. }\end{array}$ \\
\hline $\begin{array}{c}T w t w \\
\text { El-Amarna }\end{array}$ & . & $\begin{array}{l}\text { standing in } \\
\text { front of the } \\
\text { door, most } \\
\text { probably } \\
\text { verifying the } \\
\text { identity of the } \\
\text { visitors. } \\
\text { (palatial context) } \\
\end{array}$ & stick & $\begin{array}{l}\text { Davies, The } \\
\text { Rock tombs of } \\
\text { El Amarna 6, } \\
\text { pl. 20, west } \\
\text { wall, south } \\
\text { side. }\end{array}$ \\
\hline & & & & Continued \\
\hline
\end{tabular}




\begin{tabular}{|c|c|c|c|c|}
\hline $\begin{array}{l}\text { Nfr-htp } \\
\text { Thebes }\end{array}$ & $=7$ & $\begin{array}{l}\text { standing at the } \\
\text { doorway } \\
\text { (palatial } \\
\text { context) }\end{array}$ & $\begin{array}{l}\text { holding a stick } \\
\text { in one hand, } \\
\text { and something } \\
\text { unidentified in } \\
\text { the other. }\end{array}$ & $\begin{array}{l}\text { Davies, The } \\
\text { tomb of } \\
\text { Nefer-hotep } \\
\text { at Thebes I, } \\
\text { pl. 14. }\end{array}$ \\
\hline $\begin{array}{l}\text { Nfr-htp } \\
\text { Thebes }\end{array}$ & & $\begin{array}{l}\text { standing in the } \\
\text { doorway } \\
\text { (palatial } \\
\text { context) }\end{array}$ & $\begin{array}{l}\text { holding a type } \\
\text { of brush (?) in } \\
\text { one hand, and } \\
\text { waving with } \\
\text { the other. }\end{array}$ & $\begin{array}{l}\text { Davies, The } \\
\text { tomb of } \\
\text { Nefer-hotep } \\
\text { at Thebes I, } \\
\text { pl. 18. }\end{array}$ \\
\hline $\begin{array}{c}\text { Relief } \\
\text { block from } \\
\text { a tomb } \\
\text { Saqqara } \\
\text { Berlin inv. } \\
13297\end{array}$ & 10 & $\begin{array}{l}\text { standing while } \\
\text { in a sleepy } \\
\text { attitude in front } \\
\text { of the door } \\
\text { (door of temple } \\
\text { or tomb - } \\
\text { funerary } \\
\text { context) }\end{array}$ & none & $\begin{array}{l}\text { Martin, } \\
\text { Corpus of } \\
\text { Reliefs of the } \\
\text { New } \\
\text { Kingdom, pl. } \\
24.65\end{array}$ \\
\hline
\end{tabular}

\section{3 - Cleaning the floor}

Scenes from palatial contexts show varied attitudes of doorkeepers engaged in cleaning. A doorkeeper is shown sprinkling water from a jar in the tomb of Mry $R^{\text {c.67 }}{ }^{6}$ most probably to clean the floor and to bring fresh air. The doorkeeper is often shown engaged in cleaning the floor with a type of brush (e.g. tombs of Mry $R^{\mathrm{C}}{ }^{68} \mathrm{P3} \mathrm{nhsy},{ }^{69}$ $T w t w^{70}$ and $\left.H w y 3^{71}\right)$. It is to be noted that sprinkling the water from a jar was only attested twice. ${ }^{72}$ However, such remarks should not be conclusive as it should be taken into consideration that other scenes may have not survived.

Table 3 - The doorkeeper engaged in cleaning the floor

\begin{tabular}{|c|c|c|c|c|}
\hline \begin{tabular}{|c|} 
Tomb owner/ \\
Tomb location \\
\end{tabular} & Figures (details) & Description & Attributes & Reference \\
\hline $\begin{array}{c}M r y R^{\mathrm{r}} \\
\text { El-Amarna }\end{array}$ & 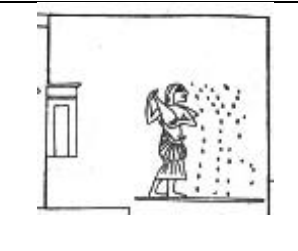 & $\begin{array}{l}\text { sprinkling water } \\
\text { from a jar. } \\
\text { (palatial context) }\end{array}$ & jar & $\begin{array}{l}\text { Davies, The } \\
\text { Rock tombs of } \\
\text { El Amarna 1, } \\
\text { pl. 18, pillared } \\
\text { hall, west wall. }\end{array}$ \\
\hline & & & & Continued \\
\hline
\end{tabular}

\footnotetext{
${ }^{67}$ Davies, N. de G., The Rock tombs of El Amarna. Part 1: The Tomb of Meryra, ASEg 13 (London, 1903), pl. 18, pillared hall, west wall.

${ }^{68}$ Davies, The Rock tombs of El Amarna. Part 1, pl. 18, pillared hall, west wall.

${ }^{69}$ Davies, The Rock tombs of El Amarna. Part 2, pl. 13, east wall.

${ }^{70}$ Davies, The Rock tombs of El Amarna. Part 6, pl. 17, west wall, north side.

${ }^{71}$ Davies, The Rock Tombs of El Amarna. Part 3, pl. 13.

${ }^{72}$ Davies, The Rock tombs of El Amarna. Part 1, pl. 18; Davies, The Rock tombs of El Amarna. Part 6, pl. 17.
} 


\begin{tabular}{|c|c|c|c|c|}
\hline $\begin{array}{c}M r y R^{r} \\
\text { El-Amarna }\end{array}$ & & $\begin{array}{l}\text { engaged in } \\
\text { cleaning using a } \\
\text { type of brush for } \\
\text { sweeping the } \\
\text { floor. } \\
\text { (palatial context) }\end{array}$ & $\begin{array}{l}\text { brush for } \\
\text { sweeping } \\
\text { the floor }\end{array}$ & $\begin{array}{l}\text { Davies, The } \\
\text { Rock tombs of } \\
\text { El Amarna 1, } \\
\text { pl. 18, pillared } \\
\text { hall, west wall. }\end{array}$ \\
\hline $\begin{array}{c}M r y R^{r} \\
\text { El-Amarna }\end{array}$ & & $\begin{array}{l}\text { engaged in } \\
\text { cleaning using a } \\
\text { type of brush for } \\
\text { sweeping the } \\
\text { floor. } \\
\text { (palatial context) }\end{array}$ & $\begin{array}{l}\text { brush for } \\
\text { sweeping } \\
\text { the floor }\end{array}$ & $\begin{array}{l}\text { Davies, The } \\
\text { Rock tombs of } \\
\text { El Amarna 1, } \\
\text { pl. 18, pillared } \\
\text { hall, west wall. }\end{array}$ \\
\hline $\begin{array}{c}\text { P3 nhsy } \\
\text { El-Amarna }\end{array}$ & & $\begin{array}{l}\text { engaged in } \\
\text { cleaning using a } \\
\text { type of brush for } \\
\text { sweeping the } \\
\text { floor. } \\
\text { (palatial context) }\end{array}$ & $\begin{array}{l}\text { brush for } \\
\text { sweeping } \\
\text { the floor }\end{array}$ & $\begin{array}{l}\text { The Rock } \\
\text { tombs of El } \\
\text { Amarna 2, pl. } \\
\text { 13, east wall. }\end{array}$ \\
\hline $\begin{array}{c}H w y 3 \\
\text { El-Ämarna }\end{array}$ & & $\begin{array}{l}\text { engaged in } \\
\text { cleaning using a } \\
\text { type of brush for } \\
\text { sweeping the } \\
\text { floor. } \\
\text { (palatial context) }\end{array}$ & $\begin{array}{l}\text { brush for } \\
\text { sweeping } \\
\text { the floor }\end{array}$ & $\begin{array}{l}\text { Davies, The } \\
\text { Rock Tombs of } \\
\text { El Amarna 3, } \\
\text { pl. 13. }\end{array}$ \\
\hline $\begin{array}{c}\text { Twtw } \\
\text { El-Amarna }\end{array}$ & 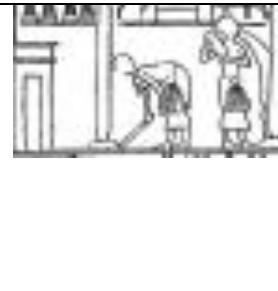 & $\begin{array}{l}\text { engaged in } \\
\text { cleaning using a } \\
\text { type of brush for } \\
\text { sweeping the } \\
\text { floor. } \\
\text { (palatial context) }\end{array}$ & $\begin{array}{l}\text { brush for } \\
\text { sweeping } \\
\text { the floor }\end{array}$ & $\begin{array}{l}\text { Davies, The } \\
\text { Rock tombs of } \\
\text { El Amarna 6, } \\
\text { pl. 17, west } \\
\text { wall, north } \\
\text { side. }\end{array}$ \\
\hline
\end{tabular}

The scene details hint at the duties of the doorkeeper. Based upon the information conveyed by the representations, we may feel confident to interpret the seated postures as indicators of the doorkeepers having been active for a long time while being engaged in guarding.

\section{Doorkeepers' attitudes}

Representations of doorkeepers were not widely attested. The stylistic parallels depicting doorkeepers' gestures and attitudes during the New Kingdom deviate from the norm as per the artistic conventions as follows:

- The doorkeeper was shown as having been provoked by others in some contexts. This may be the reason why the motif has been interpreted by Van de Walle and 
Houlihan as to reflect humor. ${ }^{73}$ Morenz likewise interpreted the rendering of the doorkeeper's sleepy figure as indicator of humor. ${ }^{74}$ The standing posture holding a stick in one hand occurred three times in the tombs of $M h w,{ }^{75} T_{w t w}{ }^{76}$ at Amarna and in the tomb of Nfr-htp at Thebes. The latter possesses the only representation which appears to be in close parallelism with the sign 1 (A59); depicting a man threatening with a stick, ${ }^{77}$ used as determinative to the verb 1 兽 78 shr 'drive away'. ${ }^{79}$ Nevertheless, in the tomb of $N f r$ - $h t p$ at Thebes the man is not raising the stick above his head's level as in the sign A59. It is additionally noteworthy that the

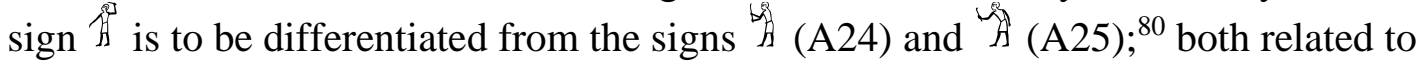
striking.

- The seated representations of doorkeepers were frequent. They are shown seated on a cushion or directly on the ground. Among the varied postures is the one showing the doorkeeper eating from a plate placed on the ground in front of him. ${ }^{81}$ The seated doorkeeper is either depicted beside, behind or in front of the door. The attitude most commonly represented is the one being in front of the door.

- The dormant representations ${ }^{82}$ of doorkeepers let us wonder whether they were napping while being work-free. Although his main task necessitated full attention, the doorkeeper was curiously often depicted as a sleepy figure; totally conforming with Davies' description of the doorkeeper in the tomb of Mry $R^{\complement}$ II as "who has nothing to do but lean idly against the door-cheek and gossip". 83 The tomb scenes available as source materials often show dormant, lazy and possibly careless doorkeepers, extremely contradicting the duty anticipated vigilance.

Doorkeepers seemingly remained inactive in their work places while being freed from work, instead of moving back to their houses. Such an observation should be taken into consideration when reconstructing the doorkeepers' functions related to their figured attitudes. It might be assumed that the doorkeeper was sitting out there for several hours. During most of the time he may not have been dealing with anyone; except for the few visitors allowed in.

\footnotetext{
${ }^{73}$ Van de Walle, B., L'humour dans la littérature et dans l'art de l'ancienne Égypte, Scholae Adriani de Buck memoriae dicatae IV (Leiden, 1969), 7; Houlihan, P. F., Wit \& humour in ancient Egypt (London, 2001), 49.

${ }^{74}$ Morenz, L.D., Kleine Archäologie des ägyptischen Humors: Ein Kulturgeschichtlicher Testschnitt, B ̈̈B 3 (Berlin, 2013), 83, 84.

${ }^{75}$ Davies, The Rock Tombs of El Amarna. Part 4, pl. 25, south end wall.

${ }^{76}$ Davies, The Rock tombs of El Amarna. Part 6, pl. 20, west wall, south side.

${ }^{77}$ Gardiner, A., Egyptian Grammar, Third edition (London, 1957), 445.

${ }^{78}$ See $W b$ IV, 219, (9)- (12); Urk. IV, 618, 7.

${ }^{79}$ Davies, The tomb of Nefer-hotep at Thebes I, pl. 14. Cf. Wb IV, 219, 220.

${ }^{80}$ Gardiner, Egyptian Grammar, 444, 445.

${ }^{81}$ Davies, The Rock tombs of El Amarna. Part 6, pl. 28, north wall, doorway.

82 Types of sleeping figures representing the far arm laid across the other on the knees were represented in the Middle and the New Kingdoms. (e.g. Cairo fragment no. 1562: Wreszinski, W., Atlas zur altägyptischen Kulturgeschichte, Volume I (Leipzig, 1923), pl. 397; Berlin fragment: Wreszinski, Atlas zur altägyptischen Kulturgeschichte I, pl. 385.

${ }^{83}$ Davies, The Rock tombs of El Amarna. Part 2, 38.
} 
- The doorkeeper's attitude of standing while placing one leg against the door at his back probably hints at having been at the place for long. Possible interactions such as chatting with a passerby, be it a colleague worker, or a visitor, could be detected. This attitude might as well suggest boredom; most probably due to the monotony of the charge. Getting bored and feeling asleep were therefore normalized with the character.

- Frontality: The doorkeeper on the relief block (Berlin inv. 13297), ${ }^{84}$ originally from a late New Kingdom tomb-chapel at Saqqara, is shown with a remarkable relaxing pose. Yet, instead of being attentive, he is rather asleep ${ }^{85}$ leaning with an arm on the door, while his head leans on the other. Frontality was used to mark his closed eyes. Nevertheless, he is unrealistically falling asleep while standing; a probable hint at the long time he had been spending at a relatively not frequented place.

\section{The interplay of motifs identifying the doorkeeper}

Using iconicity to reflect the doorkeeper's main responsibility was simply by depicting the doorway beside or behind. The place does not seem to be a guard's post; but the entrance was secured by the doorkeeper's presence. His major tasks seem to have been the opening and closing of the secured area, in addition to controlling others' movement into the place.

The doorkeeper's presence at the entrance was necessarily in association with safety. The door leaf forming part of the title iry- 3 was regularly rendered as a door or doorway in the representations. Ventura's definition of the doorkeeper's occupation evidently sums up his role as: "opening something closed (blocked physically, or just of forbidden access) to introduce (after inspection)". 86

Unlike the required qualities including a priori corporal strength of the necropolis iryw $3,{ }^{87}$ the duties of the doorkeepers in charge of ordinary houses required the ability to stay in place for a long time, in addition to having a good knowledge of the area and of the inhabitants. ${ }^{88}$ It is tempting to expect that the doorkeeper would consequently be residing in the nearby area. Besides, the doorkeeper should have been a trustworthy person. ${ }^{89}$

In iconography doorkeepers were merely shown on duty. Identifying the motif hence mostly depended on his attributes, in addition to the scene contextual analysis.

- The doorkeeper was usually associated with the door; his main job was to guard the access to an area or a place. A double-leaved door is usually shown closed but never bolted. The door was usually either represented behind or beside the

\footnotetext{
${ }^{84}$ Wreszinski, Atlas zur altägyptischen Kulturgeschichte I, pl. 91 c.

${ }^{85}$ Morenz, Kleine Archäologie des ägyptischen Humors, 83.

${ }^{86}$ Ventura, Living in a city of the dead, 113.

${ }^{87}$ Ventura, Living in a city of the dead, 108, 109.

${ }^{88}$ Goecke-Bauer, “Untersuchungen zu den 'Torwächtern' von Deir el Medine”, 140.

${ }^{89}$ Goecke-Bauer, “Untersuchungen zu den 'Torwächtern' von Deir el Medine”, 140, 142.
} 
doorkeeper's figure. The difference in scale between the man's size and that of the door is not unusual. ${ }^{90}$

- The stick or baton that he carries is evidently more suggestive of his character, and is indicative of his role. The stick hints at the act of threatening; probably in case of intruders. Yet, the doorkeeper was not equipped with a stick in all representations.

- The brush for sweeping the floor seems to be one of the doorkeeper's attributes. Using the brush to sweep the floor should be in association with the verb $\bar{l} s k$ "wipe". ${ }^{91} P 3-h r-n$-hnsw was 'porter of Amon temple', and was depicted with obvious obesity wearing a fine linen costume. His figure shows him holding in his right hand the brush used for sweeping the floor as marker of his charge. ${ }^{92}$

- The particularity of rendering the doorkeeper's status as dormant is markedly not frequent. Less frequent than the documents depicting the doorkeeper engaged in cleaning the floor or sprinkling water from a jar, are the ones depicting him lazy. It is noteworthy that the motif showing the hand supporting the head was introduced in the New Kingdom. ${ }^{93}$

- The question arises whether the doorkeeper's responsibility merely involved watching duties. It is of importance to conveniently summarize the features, in order to highlight the doorkeeper's functions. The duties involved inspection and allowing to pass the door or the gate. The main role assigned to the doorkeeper was inspecting on visitors allowed in and those who were not, according to the rules of the institutions they were attached to. In the tomb of Nfr-htp at Thebes one of the doorkeepers carries the scribe's palette, most probably to note the visitors' names. ${ }^{94}$ Verifying who the visitors or passersby wishing to have access to the place was evidently an integral part of the doorkeeper's duty. ${ }^{95}$ In the tomb of $P 3 r n n f r$ at Amarna, ${ }^{96}$ the doorkeeper is holding the palette and a brush pen to register the articles brought into the store.

${ }^{90}$ Cf. Wreszinski, W., Atlas zur altägyptischen Kulturgeschichte, Teil III: Gräber des Alten Reiches (bearbeitet von H. Schäfer) (Leipzig, 1936), 151.

${ }^{91}$ Faulkner, R. O., A Concise Dictionary of Middle Egyptian (Oxford, 1988), 250. For examples of types of brushes see: Felgenhauer, A., Aus Gräbern, Heiligtümern und Siedlungen: Die altägyptische Sammlung des Übersee-Museums Bremen (Darmstadt, 2015), 128, fig. 172.

${ }^{92}$ Ghalioungui, P., "Sur deux formes dobésité représentées dans l'Égypte ancienne", ASAE 49 (1949), 316, fig. 16; Guilhou, N., "Génies funéraires, croquet-mitaines ou anges gardiens ? Étude sur les fouets, balais, palmes et épis en guise de couteaux", in S.H. Aufrère, Encyclopédie religieuse de l'Univers végétal - Croyances phytoreligieuses de l'Égypte ancienne I, Orientalia Monspeliensia X (Montpellier, 1999), 383, 386, fig. 42.

${ }_{93}^{93}$ Morenz, Kleine Archäologie des ägyptischen Humors, 83.

${ }^{94}$ Davies, The tomb of Nefer-hotep at Thebes I, pl. XVI, 2.

${ }^{95}$ Sweeney, D., Correspondence and Dialogue: Pragmatic Factors in Late Ramesside Letter-Writing, ÄAT 49 (Wiesbaden, 2001), 123. An interrogation of a gang of robbers included the following question: "You are the doorkeeper of this place. Please name every man whom you saw." (pBM 10403, r1.4).

${ }^{96}$ Davies, The Rock tombs of El Amarna. Part 6, pl. 4, west wall. 
Other types of documents belong to the workmen community from Deir el-Medineh. The study of Deir el-Medineh doorkeepers ${ }^{97}$ includes attestations of routine activities. Side activities were assigned to the doorkeeper, yet, seemingly not on a regular basis. In Deir el-Medineh one of the doorkeepers assisted the representatives of the crew in receiving the delivered products. For that he was stated to be the person "through whose hand" ( $m$ - $\underline{d r t}$ ) the provisions were brought at the enclosure of the necropolis. ${ }^{98}$

\section{Three dimensional representations of doorkeepers}

The earliest three dimensional representations of doorkeepers are models dating from the Eleventh Dynasty of the Middle Kingdom. The tomb of $M k t-R^{e}$ included doorkeepers ${ }^{99}$ in the models of the stable (D), ${ }^{100}$ the granary $(\mathrm{F}),{ }^{101}$ the brewery and bakery $(\mathrm{G}){ }^{102}$

The model of the stable (D): (fig. 1) The front half of the stable appears as an unroofed yard. The stable entrance door is guarded by a seated doorkeeper holding his stick. Winlock interpreted the function of the stick as either to be used to stop intruders or to prevent the escape of animals from the stable. ${ }^{103}$

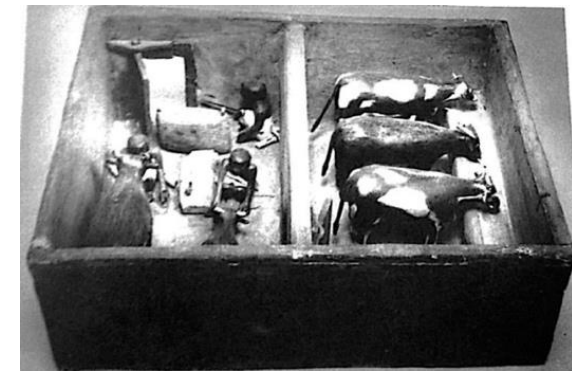

Fig. 1. Cattle stable model, tomb of $M k t-R^{\mathbf{r}}$

After: Winlock, Models of Daily Life in Ancient Egypt, pl. 17.

The model of the granary (F): (fig. 2) The granary was unroofed like the modern Egyptian one called in Arabic (شونة). ${ }^{104}$ The entrance has a cleated door, where the guardian was shown squatting with a stick in hand. Four scribes sitting near him are busy counting the grain baskets.

\footnotetext{
${ }^{97}$ Goecke-Bauer, “Untersuchungen zu den 'Torwächtern' von Deir el Medine”, 64.

98 Janssen, Jac. J., Village Varia: Ten Studies on the History and Administration of Deir-el-Medina, EgUit 11 (Leiden, 1997), 7.

${ }^{99}$ Leprohon, R. J., "Gatekeepers of This and the Other World", JSSEA XXIV (1994), 81.

${ }^{100}$ Winlock, Models of Daily Life in Ancient Egypt from the Tomb of Meket-Re $\bar{e}^{\varphi}$ at Thebes, pl. 17.

${ }^{101}$ Winlock, Models of Daily Life in Ancient Egypt from the Tomb of Meket-Re $\bar{e}^{\varsigma}$ at Thebes, pl. 20.

102 Winlock, Models of Daily Life in Ancient Egypt from the Tomb of Meket-Re $\bar{e}^{\varsigma}$ at Thebes, pls. $22,23$.

${ }^{103}$ Winlock, Models of Daily Life in Ancient Egypt from the Tomb of Meket-R $\bar{e}^{\varsigma}$ at Thebes, 22.

${ }^{104}$ Winlock, Models of Daily Life in Ancient Egypt from the Tomb of Meket-R $\bar{e}^{\varsigma}$ at Thebes, 25.
} 


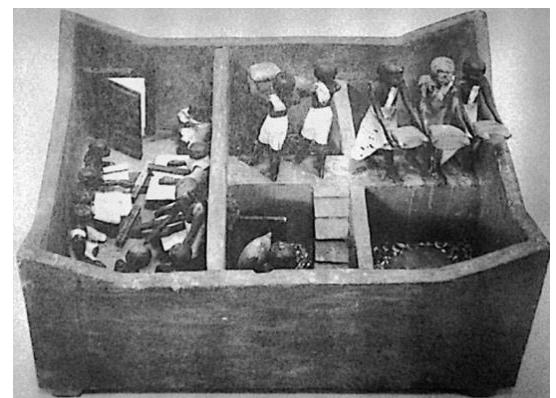

Fig. 2 Granary model, tomb of $M k t-R^{\boldsymbol{c}}$

After: Winlock, Models of Daily Life in Ancient Egypt, pl. 22.

The models of the brewery and bakery (G): (fig. 3) Bakers and brewers share one building divided by a high partition wall. A door through the partition wall connects the two small rooms. This is where the doorkeeper is seated with a stick in his hand; while guarding both the brewery and the bakery. ${ }^{105}$

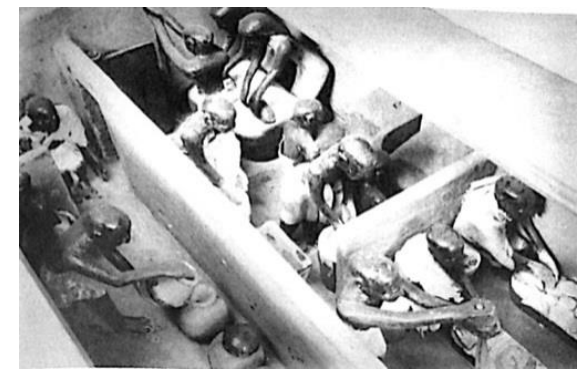

Fig. 3. Brewery and bakery model, tomb of $M k t-R^{r}$

After: Winlock, Models of Daily Life in Ancient Egypt, pl. 25.

\section{Scene analysis and interpretation}

Attestations of pictured doorkeepers only appeared on private tomb walls and date to the Eighteenth and Nineteenth Dynasties. It is possible to identify their figures, even with the absence of inscriptions, due to their attributes highlighting particular aspects of the character.

The scenes display a remarkable parallelism in depicting the doorkeeper, however with a degree of individuality allowing a sense of freedom in representing the details, gestures and postures. It is noteworthy that all representations of doorkeepers are minor figures shown in palace interiors or at the entrance to storage areas.

\section{Tomb of Mry $\boldsymbol{R}^{\boldsymbol{r}}$, El-Amarna}

Location: pillared hall, west wall depicting the palace ${ }^{106}$

The scene includes five representations of doorkeepers (fig. 4). In the upper register, to the right side, one of them is sprinkling water from a jar, most probably to clean the floor. In the lowest register, two doorkeepers one to the right side, and the other to the left side, are both engaged in cleaning the floor with a type of brush. To the left side in the upper register, a doorkeeper stands in front of the door. Another figure is a bit reclining in front of a door.

${ }^{105}$ Winlock, Models of Daily Life in Ancient Egypt from the Tomb of Meket-Ré $\bar{e}^{\varsigma}$ at Thebes, 27.

${ }^{106}$ Davies, The Rock tombs of El Amarna. Part 1, pl. 18, pillared hall, west wall. 


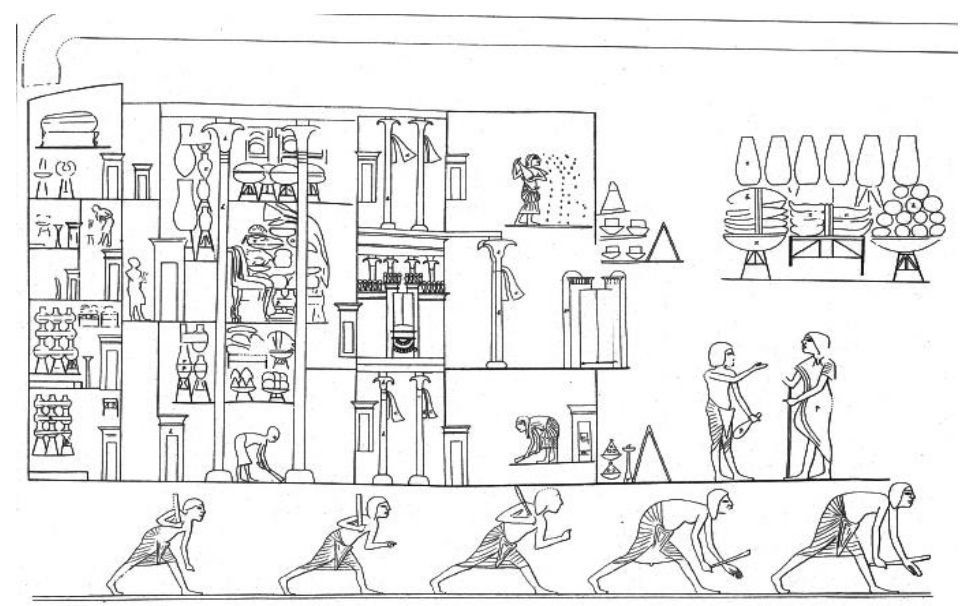

Fig. 4. Detail of the west wall, tomb of $M r y R^{\Upsilon}$, El-Amarna

After: Davies, The Rock tombs of El Amarna. Part 1, pl. 18, pillared hall.

\section{Tomb of $P 3$ nhsy, El-Amarna}

Location: east wall ${ }^{107}$

The major scene on the wall depicts Akhenaton standing in his chariot, followed by the queen driving her chariot. The princesses also follow in chariots on smaller scale. The military escort is shown in front of the king and in the register below. ${ }^{108}$ Fragments of the greeting crowd remain at the top of the wall. ${ }^{109}$ The palace is depicted in the top right-hand corner. This is where two doorkeepers can be detected; one to the left side and the other to the right side (fig. 5).

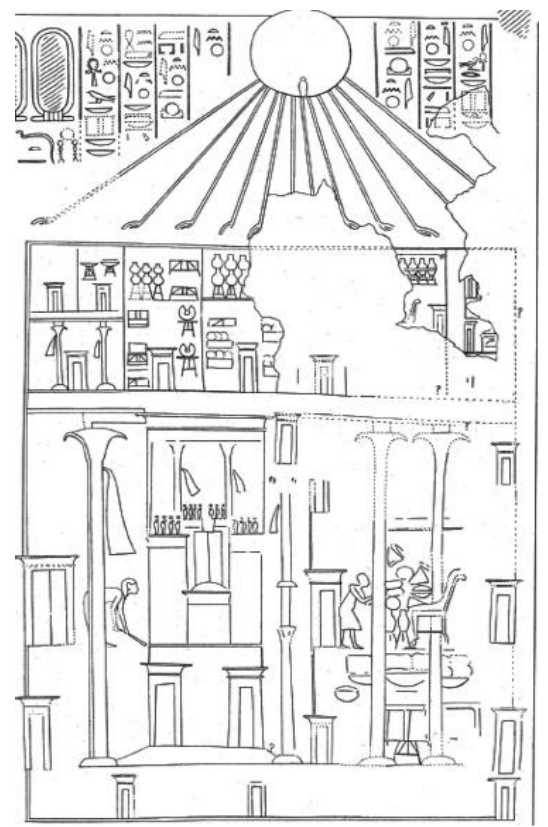

Fig. 5. Detail of the east wall, tomb of $P 3$ nhsy, El-Amarna

After: Davies, The Rock tombs of El Amarna. Part 2, pl. 14.

${ }^{107}$ Davies, The Rock tombs of El Amarna. Part 2, pl. 14, east wall.

${ }^{108}$ Davies, The Rock tombs of El Amarna. Part 2, 18.

${ }^{109}$ Davies, The Rock tombs of El Amarna. Part 2, 19. 


\section{Tomb of Mry $R^{\mathrm{e}}$ II, El-Amarna}

Location: south wall, east side ${ }^{110}$

The wall depicts the bestowal of golden necklaces on Mry $R^{\ulcorner}$II as proof of royal favor. Besides the main scene showing the façade of the royal palace, and some parts of the palace interior. A doorkeeper is shown leaning with one leg bent and leaned against the door at his back while waving his arm. He is seemingly talking to the house-boy sprinkling the floor with water from a jar (fig. 6).

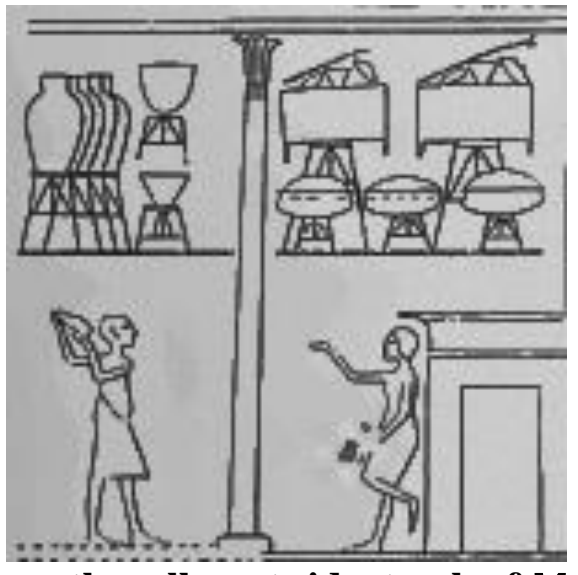

Fig. 6. Detail of the south wall, east side, tomb of $M r y R^{\mathbf{e}}$ II, El-Amarna After: Davies, The Rock tombs of El Amarna. Part 2, pl. 36.

\section{Tomb of Hwy3, El-Amarna}

Location: west wall ${ }^{111}$

The wall shows the royal palanquin with the palace and its interiors occupying part of the scene. The details show a sleepy doorkeeper in the corridor, ${ }^{112}$ while another is figured sweeping the floor with a type of brush (fig. 7).

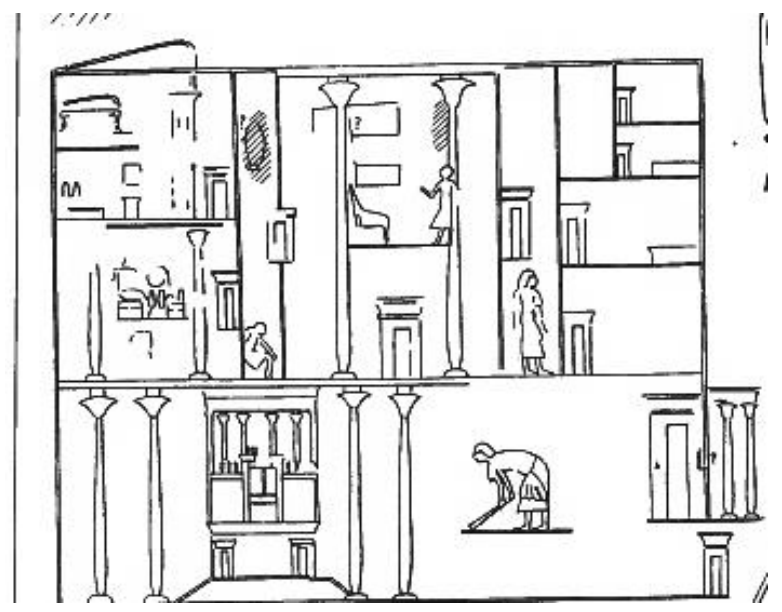

Fig. 7. Detail of the west wall, tomb of $\boldsymbol{H} w y$, El-Amarna

After: Davies, The Rock Tombs of El Amarna. Part 3, pl. XIII, palace interiors.

${ }^{110}$ Davies, The Rock tombs of El Amarna. Part 2, 38, pl. 33, detail in pl. 36, south wall, east side.

${ }^{111}$ Davies, The Rock Tombs of El Amarna. Part 3, 10, pl 13.

${ }^{112}$ Davies, The Rock Tombs of El Amarna. Part 3, 10, pl 13; LD III, 106 a. 


\section{Tomb of $M h \mathfrak{h}$, El-Amarna}

Location: front wall, south side. ${ }^{113}$

The wall depicts $M h w w$ overseeing the guard-houses of which the inner arrangement appears as three stores. The ground floor seems to be used for the food storage; while the room above is apparently a guard room where a doorkeeper stands in front of the doorway holding a stick (fig. 8). ${ }^{114}$

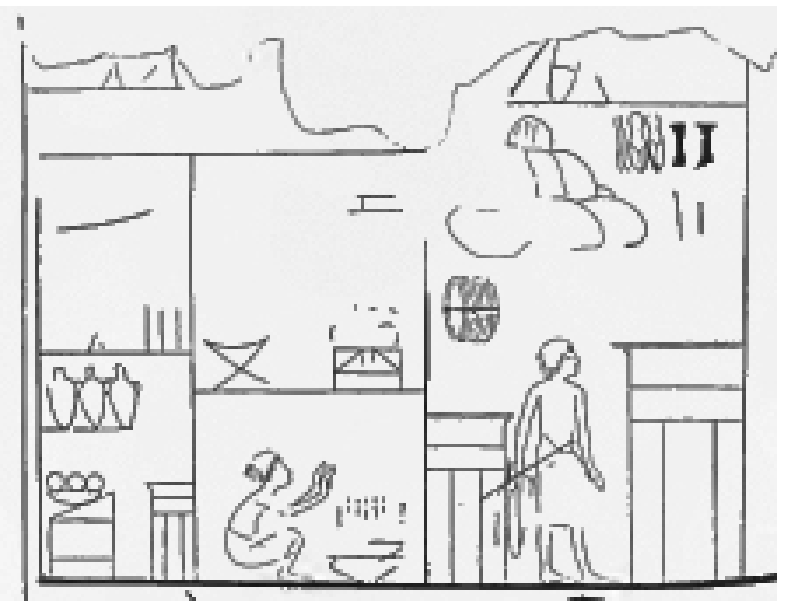

Fig. 8. Detail of the south end wall, tomb of $M h w$, El-Amarna

After: Davies, The Rock Tombs of El Amarna. Part 4, pl. 25.

\section{Tomb of $P 3 r n n f r$, El-Amarna}

Location: west wall ${ }^{115}$

The scene on the west wall depicts the bestowal of rewards on $P 3 r n n f r$. In the lower register, servants are shown heading to the stores, carrying off jars and baskets. To the right side of the file stand two guardians (fig. 9). To the left side, another guardian seems to be registering the articles brought in. His figure was described by Davies as being that of a scribe. ${ }^{116}$ Yet, it is likely to be that of a guardian; doorkeepers proved to have been assigned the duty of registering visitors' names in paralleled scenes.

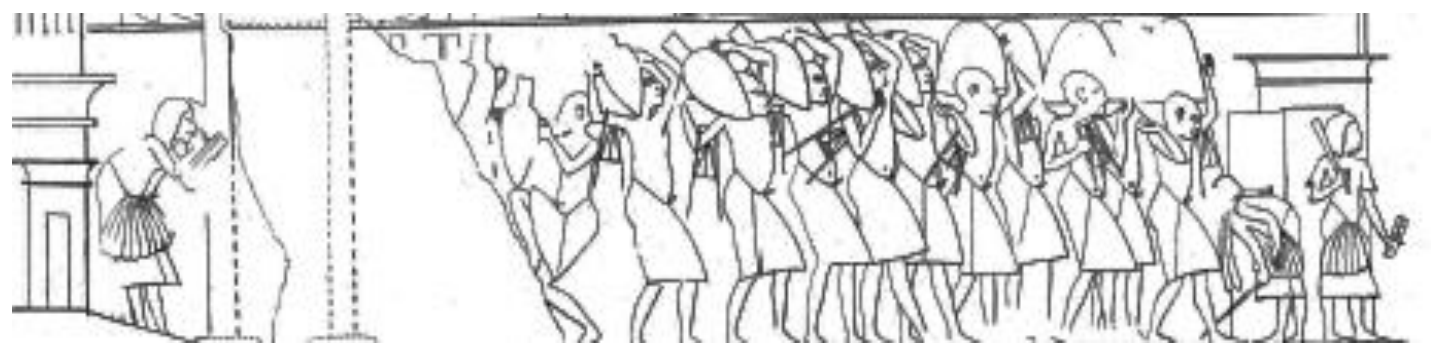

Fig. 9. Detail of the west wall, tomb of $P 3 r n n f r$, El-Amarna After: Davies, The Rock tombs of El Amarna. Part 6, pl. 4.

\footnotetext{
${ }^{113}$ Davies, The Rock Tombs of El Amarna. Part 4, pl. 25, south end wall.

${ }^{114}$ Davies, The Rock Tombs of El Amarna. Part 4, 17.

115 Davies, The Rock tombs of El Amarna. Part 6, pl. 4, west wall.

${ }^{116}$ Davies, The Rock tombs of El Amarna. Part 6, 4.
} 


\section{Tomb of Twtw, El-Amarna}

Location: west wall, south side ${ }^{117}$

The major scene on the wall depicts Twtw receiving promotion from the king. ${ }^{118}$ The interiors of the palace show several varied postures of doorkeepers. One is engaged in cleaning the floor with a type of brush, while two others are shown, each sitting on a cushion in front of a door. A fourth guardian is depicted standing while leaning with one leg against the door at his back (fig. 10). This posture parallels the ones shown in the tombs of Mry $R^{\mathrm{C}} \mathrm{II}$ (fig. 6) ${ }^{119}$ and Ty (fig. 14a). ${ }^{120}$

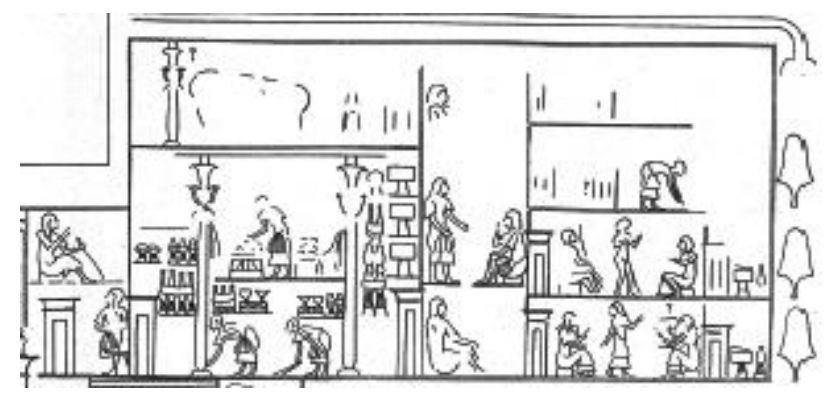

Fig. 10. Detail of the west wall, south side, tomb of $T w t w$, El-Amarna

After: Davies, The Rock tombs of El Amarna. Part 6, pl. 17.

On the south side of the same wall in the lowest register, ${ }^{121}$ chariots convey officials to and from the palace. ${ }^{122} \mathrm{~A}$ guard standing at the gate seems to be verifying the identity of those wishing to enter (fig. 11). In the same register, a doorkeeper is depicted using a kind of brush for sweeping the floor (fig. 12).

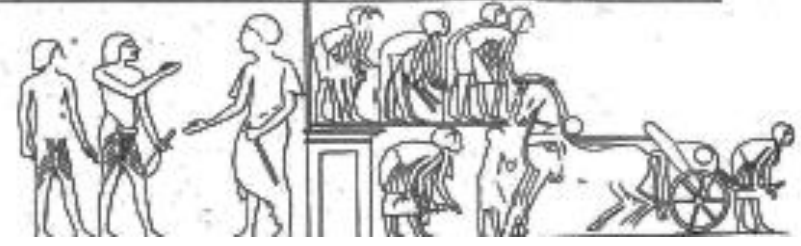

Fig. 11. Detail of the west wall, south side, tomb of Twtw, El-Amarna

After: Davies, The Rock tombs of El Amarna. Part 6, pl. 20.

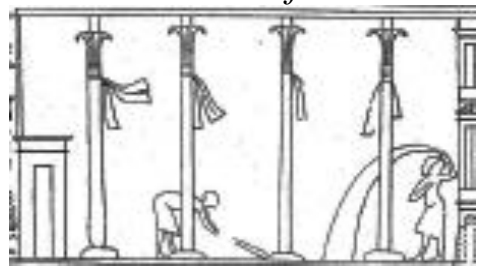

Fig. 12. Detail of the west wall, south side, tomb of Twtw, El-Amarna

After: Davies, The Rock tombs of El Amarna. Part 6, pl. 19.

\footnotetext{
${ }^{117}$ Davies, The Rock tombs of El Amarna. Part 6, pl. 19, west wall, south side.

118 Davies, The Rock tombs of El Amarna. Part 6, 12, 13.

${ }^{119}$ Davies, The Rock tombs of El Amarna. Part 2, 38, pl. 33, detail in pl. XXXVI, south wall, east side.

${ }^{120}$ Davies, The Rock tombs of El Amarna. Part 6, pl. 28, north wall, doorway.

${ }^{121}$ Davies, The Rock tombs of El Amarna. Part 6, pl. 20, west wall, south side

${ }^{122}$ Davies, The Rock tombs of El Amarna. Part 6, 13; pl. 20.
} 


\section{The tomb of $7 y$, El-Amarna}

Location: north wall, doorway ${ }^{123}$

The main scene on the wall is dominated by the balcony of the royal family. The palace is depicted with one building apparently comprising a storehouse for servants. ${ }^{124}$ Another building shows the harem quarters assigned to female servants (fig. 13). Male doorkeepers are only depicted by the doors in varied poses; one is eating while another is sleepy. Female musicians and servants are shown inside, some engaged in eating.

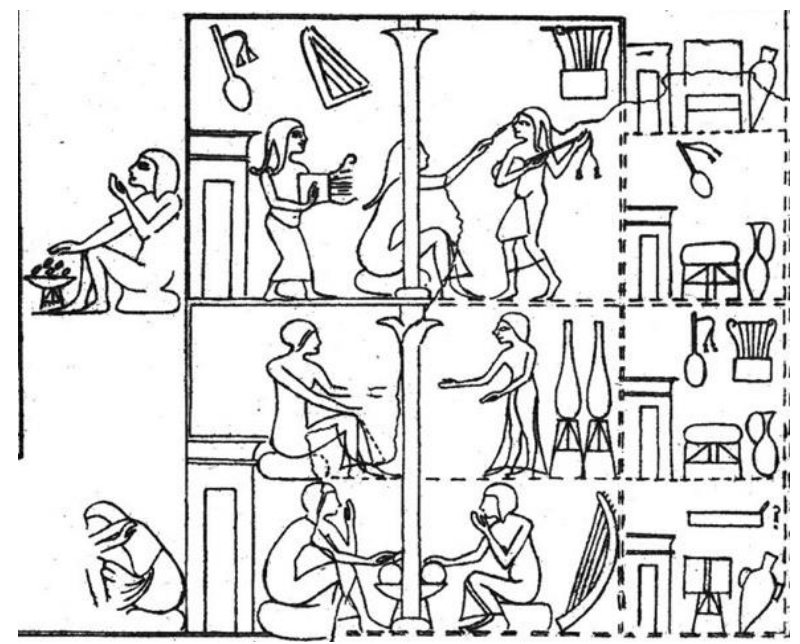

Fig. 13. Detail of the doorway, tomb of $7 i$, El-Amarna

After: Davies, The Rock tombs of El Amarna. Part 6, pl. 28.

The scenes on the architrave also show female musicians inside the harem. ${ }^{125} \mathrm{~A}$ doorkeeper is shown outside, chatting with another person while leaning with his leg against the door at his back (fig. 14a). Another doorkeeper is shown outside, sitting on a cushion (fig. 14b). In the same scene to the left, a doorkeeper standing at the door, is seemingly talking with a person before allowing him in (fig. 14c). ${ }^{126}$

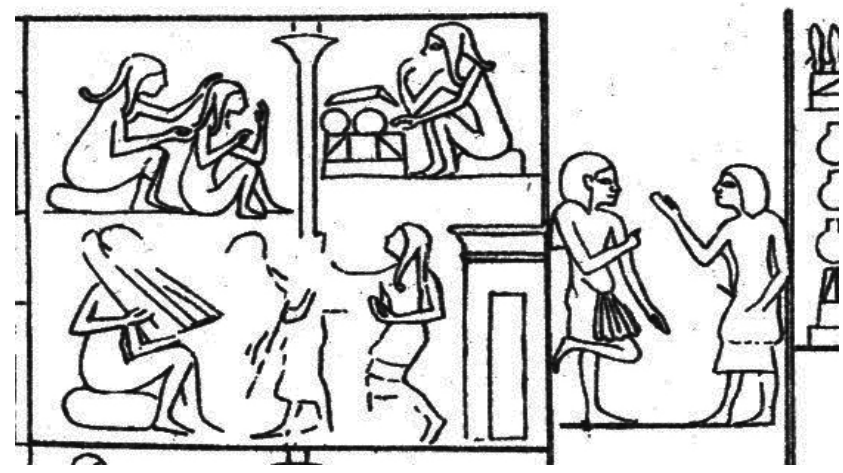

Fig. 14a. Detail of the north wall, architrave, tomb of ' $I$, El-Amarna After: Davies, The Rock tombs of El Amarna. Part 6, pl. 28.

\footnotetext{
${ }^{123}$ Davies, The Rock tombs of El Amarna. Part 6, 20, pl. 28, north wall, doorway.

${ }^{124}$ Davies, The Rock tombs of El Amarna. Part 6, 19, pl. 28.

${ }^{125}$ Davies, The Rock tombs of El Amarna. Part 6, 19, pl. 28, north wall, architrave.

${ }^{126}$ Davies, The Rock tombs of El Amarna. Part 6, 19, pl. 28, north wall, architrave.
} 


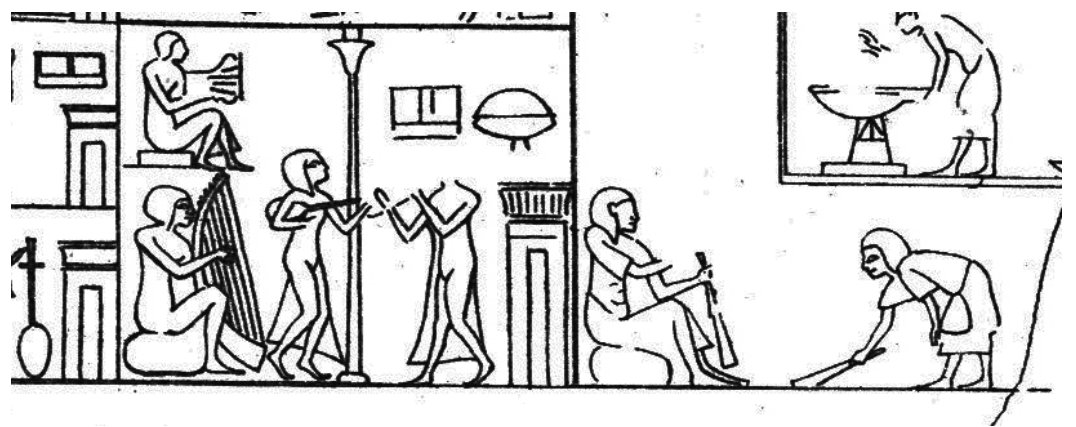

Fig. 14b. Detail of the north wall, architrave, tomb of $T$, El-Amarna After: Davies, The Rock tombs of El Amarna. Part 6, pl. 28, left side.

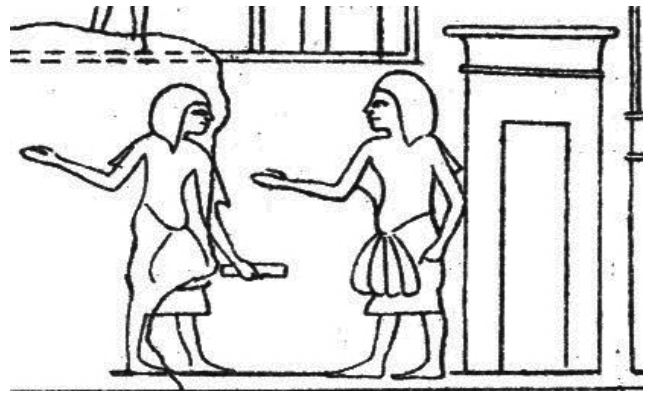

Fig. 14c. Detail of the north wall, architrave, tomb of $T$, El-Amarna After: Davies, The Rock tombs of El Amarna. Part 6, pl. 28, left side.

\section{Tomb of Ini-iti.f, Dra ${ }^{\top}$ Abu el-Naga, Thebes (TT 155) ${ }^{127}$}

Location: hall, back wall

The right part of the back wall bears a wall painting showing wine jars being carried off to a cellar. The four jar carriers are supervised by an overseer (fig. 15). The latter calls out the jar carriers to hurry: 'Move on! We will scorch ourselves (out here in the sun)'. ${ }^{128}$ The last one carrying the heavy jar on his shoulder adds: 'Behold, the load is heavy'. ${ }^{129}$

The first jar carrier had reached the door but found it closed. Having not received any response after knocking at the door, he addressed the colleague behind him saying:

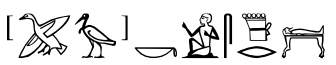

$[p 3 b 3] k s \underline{d r}$

The servant (i.e. the doorkeeper) is sleeping.

His companion guessed that the doorkeeper should be drunk, and thus adds:

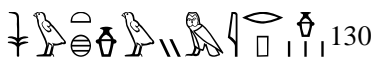

127 The tomb dates to the Eighteenth Dynasty (reign of Hatchepsut, Thutmosis III). Guglielmi, Reden, Rufe und Lieder, 87.

${ }^{128}$ Houlihan, Wit \& humour in ancient Egypt, 49.

${ }^{129}$ Säve-Söderbergh, T., Four eighteenth Dynasty tombs, Private Tombs at Thebes I (Oxford, 1957), 18; Guglielmi, Reden, Rufe und Lieder, 89; Houlihan, Wit \& humour in ancient Egypt, 49.

${ }^{130}$ The right end of the sub-scene was copied and published by Wilkinson, J., (The manners and customs of the ancient Egyptians, ed. Birch, Volume I (London, 1878), 388, no. 165). 
sw $t^{131} . w y$ m irp

He is drunk on the wine. ${ }^{132}$

The doorkeeper shown inside behind the door, crouching with his head leaned on his hand, reacts by saying:

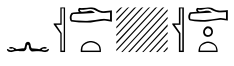

$n k d^{133}[. i] k d t$

I have not been sleeping at all. ${ }^{134}$

According to Säve-Söderbergh, the wavy walls surrounding the jars possibly hint at an enclosure wall. The place would thus probably be a temporary shelter where the wine was kept before being transported. ${ }^{135}$

Houlihan suggested that the scene might have been humoristically rendered. ${ }^{136}$ The texts tend to criticize the doorkeeper reported sleepy. The jar carriers seem bothered; having been waiting at the door. ${ }^{137}$

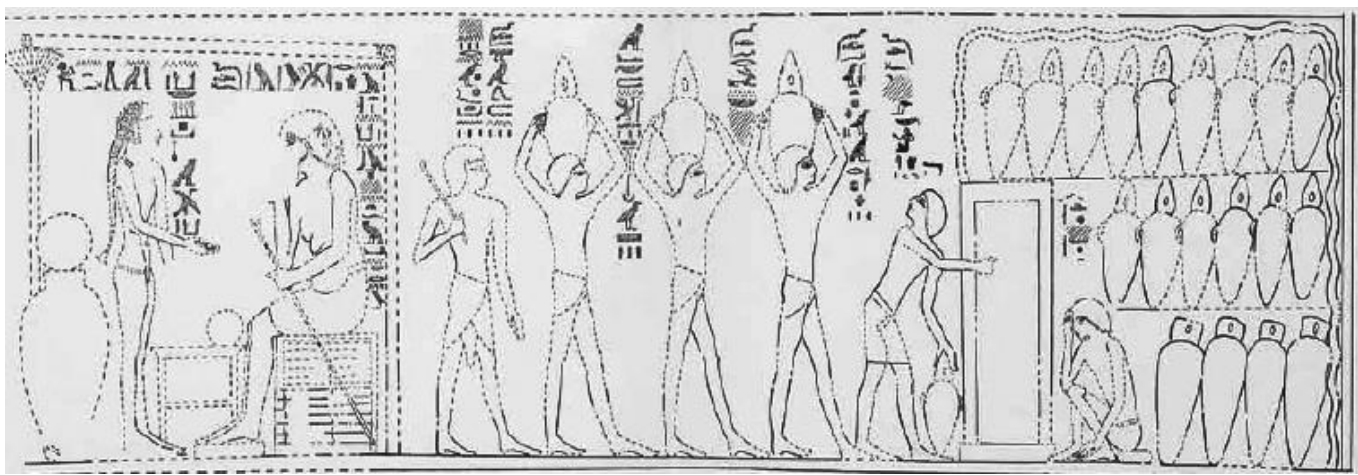

Fig. 15. Detail of the hall, sub-scene, tomb of Ini iti.f, Thebes

After: Säve-Söderbergh, Four eighteenth Dynasty tombs, pl. 15.

\section{Tomb of Nfr-htp, Thebes (TT 49)}

Location: west wall, south side ${ }^{138}$

The tomb of Nfr-htp has been dated to the beginning of the Nineteenth Dynasty. ${ }^{139}$ The major scene on the south side of the west wall shows the queen from an upper

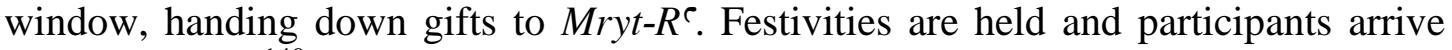
for celebration. ${ }^{140}$ The scene might be expressive of the stage before allowing them

\footnotetext{
${ }^{131} \mathrm{~Wb} \mathrm{~V}, 325,(5)$.

132 Cf. Walle, L'humour dans la littérature et dans l'art de l'ancienne Égypte, 7; Guglielmi, Reden, Rufe und Lieder, 90.

${ }^{133} \mathrm{~Wb} \mathrm{~V}, 78,(11)-(13)$, with the sign $₫$ to be emended as the missing determinative .

${ }^{134}$ Säve-Söderbergh, Four eighteenth Dynasty tombs, 18, n. 8; Guglielmi, Reden, Rufe und Lieder, 90.

135 Säve-Söderbergh, Four eighteenth Dynasty tombs, 18.

${ }^{136}$ Houlihan, Wit \& humour in ancient Egypt, 49.

${ }^{137}$ Walle, L'humour dans la littérature et dans l'art de l'ancienne Égypte, 7.

138 Davies, The tomb of Nefer-hotep at Thebes I, pl. 14, 18.

${ }^{139}$ See Wreszinski, Atlas zur altägyptischen Kulturgeschichte I, pl. 170.

${ }^{140}$ Wreszinski, Atlas zur altägyptischen Kulturgeschichte I, pl. 172.
} 
access. ${ }^{141}$ A doorkeeper stands in front of a building, while a woman and two children are shown passing by. Being discontented by the children, the guardian seems to be chasing them away with the stick (fig. 16).

In the same tomb provisions for the banquet are being brought into a room. ${ }^{142}$ Two doorkeepers watch the men bringing in the feast supplies (fig. 17).

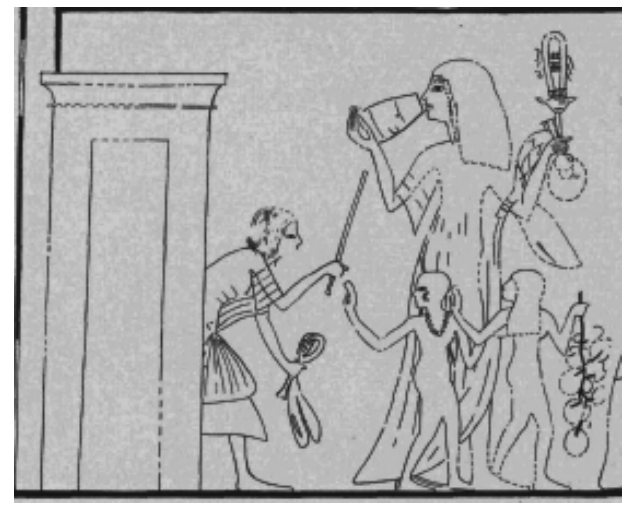

Fig. 16. Detail of the west wall, south side, tomb of $N f$ r- $h t p$, Thebes After: Davies, The tomb of Nefer-hotep at Thebes I, pl. 14.

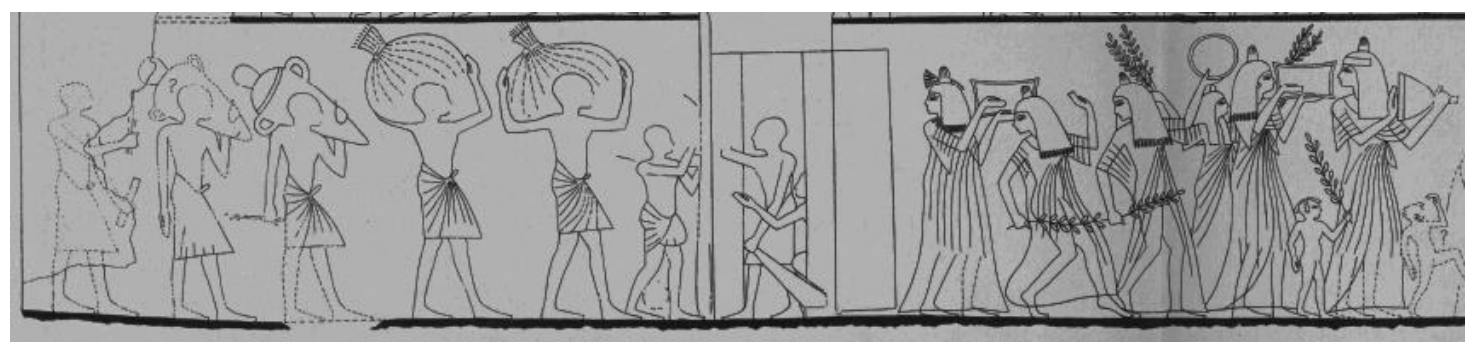

Fig. 17. Detail of the west wall, south side, tomb of $N f r-h t p$, Thebes After: Davies, The tomb of Nefer-hotep at Thebes I, pl. 18.

The main scene on the west wall shows $N f r-h t p$ leaving the palace in a chariot. A sub register shows small scaled figures among which is a doorkeeper holding a scribe's palette indicative of his duty to note visitors' names. ${ }^{143}$ The porter is further shown lifting a stick (fig. 18). ${ }^{144}$

${ }^{141}$ Davies, The tomb of Nefer-hotep at Thebes I, 25.

${ }^{142}$ Davies, The tomb of Nefer-hotep at Thebes I, 27, pl. 18.

143 See Davies, The tomb of Nefer-hotep at Thebes I, 22.

${ }^{144}$ Davies, The tomb of Nefer-hotep at Thebes I, 22, pl. 16. 


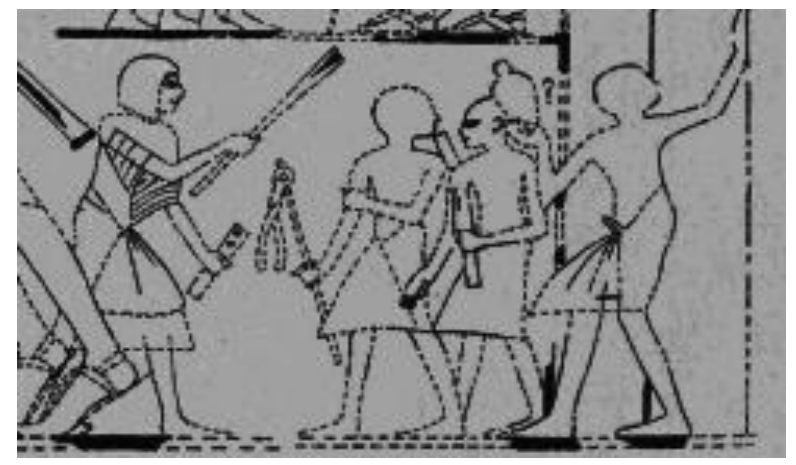

Fig. 18. Detail of the west wall, tomb of $N f r-h t p$, Thebes

After: Davies, The tomb of Nefer-hotep at Thebes I, pl. 16.

\section{Relief block Berlin inv. 13297}

\section{Originally from a New Kingdom tomb-chapel at Saqqara}

The block dates to the Eigthteenth or the Nineteenth Dynasty, ${ }^{145}$ and bears a major scene depicting a file of priests. A frontal representation of a sleepy doorkeeper shows him standing on one leg and leaning against the doorpost. He seems to be stationed there during his master's funerary ceremonies (fig. 19). ${ }^{146}$ The sleeping attitude is accentuated by the doorkeeper's closed eyes marked in frontal view. ${ }^{147}$

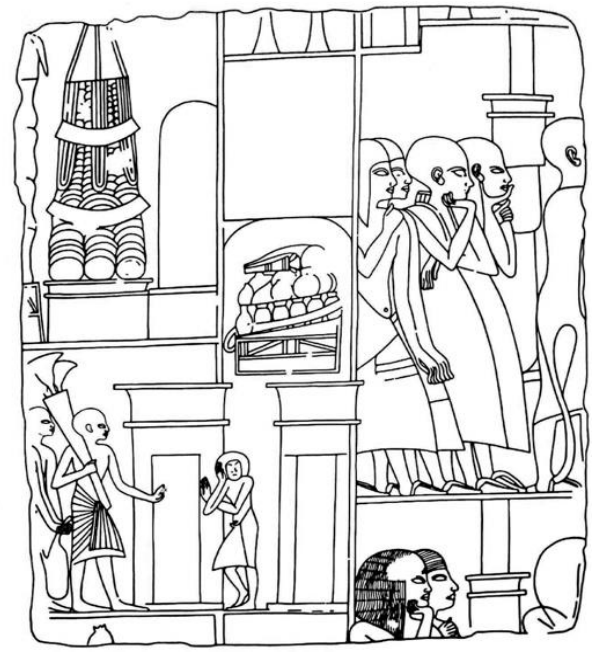

Fig. 19. Berlin, inv. 13297, originally from a New Kingdom tomb at Saqqara After: Martin, Corpus of Reliefs of the New Kingdom, pl. 69.

\section{Were block statues representations of porters?}

Leprohon ${ }^{148}$ suggested that block statues were three dimensional representations of porters sitting on the ground before the door. Yet, it is questionable whether all

\footnotetext{
145 Martin, G. T., Corpus of Reliefs of the New Kingdom from the Memphite Necropolis and lower Egypt (London, 1987), 27, 28, pl. 24.65.

146 Morenz, Kleine Archäologie des ägyptischen Humors, 83; Houlihan, Wit \& humour in ancient Egypt, 47, fig. 44; Volokhine, Y., La frontalité dans l'iconographie de l'Égypte ancienne, CSEG 6 (Geneva, 2000), 35.

${ }^{147}$ Morenz, Kleine Archäologie des ägyptischen Humors, 83.

${ }^{148}$ Leprohon, "Gatekeepers of This and the Other World", 81.
} 
holders of the title iry- 3 functioned as doorkeepers. Two block-statues dated to Ramsses II and belonging to Min ms (Brighton Museum at the United Kingdom) ${ }^{149}$ and Pi3y (M. Albert Husson collection in Lyon) ${ }^{150}$ provide related information. Both statues bear inscriptions confirming the identity of their possessors, each designated as iry- ${ }^{\varsigma_{3}}$ 'doorkeeper' of a divinity, or of its temple. ${ }^{151}$

On the block statue of Min ms he manifests himself as 'doorkeeper of the temple':

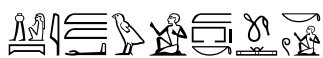

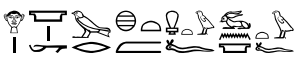

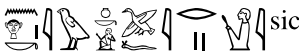

In-hry imi wi m pr. $k^{152} r w \underline{d}^{153} . k w i$

hr 9 wr ht $m$ htmw.f wn.tw.f

$n$ hr.k iw ink p3.firy ${ }^{154}-3$

O Onouris! Place (i.e. allow) me in your temple, being durable

at the great door, whether it is closed or whether it is opened

in front of you, (for) I am indeed ${ }^{155}$ his doorkeeper. ${ }^{156}$

The inscriptions confirm that Min ms was doorkeeper of the temple ( $p r)$ of 'In-hry or of the great portal $\left({ }^{\circ} \mathrm{wr}\right)$ of that temple. ${ }^{157}$

The inscriptions on the block statue of Pi3y likewise reveal his identity as doorkeeper as follows:

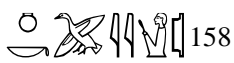

ink $p 3 y(. t)^{159}$ iry-?

I am (your) doorkeeper.

The translation of the text $p 3 y(. t)$ iry- 3 hint at being doorkeeper of the goddess Wrt $h k 3 w$, i.e. of her temple. The reading $\smile$.t of the second person feminine singular is

\footnotetext{
${ }^{149}$ Clère, "Deux statues 'gardiennes de porte', 136, n. 1, pl. XXI.

${ }^{150}$ Clère, "Deux statues 'gardiennes de porte', 138 ff., pl. XXII.

${ }^{151}$ Clère, "Deux statues 'gardiennes de porte', 141.

152 The phrase imi wi $m$ pr.k in this context means 'accept my statue in your temple'. The statues make allusions to both the real life of their possessors and to their life in the Netherworld. See Clère, "Deux statues 'gardiennes de porte', 146.

${ }^{153} \mathrm{~Wb}$ II, 411, (25).

${ }^{154}$ The sign 4 was seemingly confused instead of []. Clère, "Deux statues 'gardiennes de porte', 137.

${ }^{155}$ For the construction $i w$ + independent pronoun, here iw ink: Erman, A., Neuaegyptische Grammatik (Leipzig, 1880), § 520; Gardiner, Egyptian Grammar, § 468, 3.

${ }^{156}$ Clère, "Deux statues 'gardiennes de porte", 137.

${ }^{157}$ Clère, "Deux statues 'gardiennes de porte", 141.

${ }^{158}$ Clère, "Deux statues 'gardiennes de porte", pl. XXIII, K.

${ }^{159}$ Clère, "Deux statues 'gardiennes de porte", 140, n. 1. Cf. Erman, Neuägyptische Grammatik, § 68 ; $W b \mathrm{~V}, 337$.
} 
implied by the graphical occurence $\backsim$ on the same statue in ear'.

Min ms, the owner of the Brighton statue, was 'first prophet of 'In-hry' at Abydos, and held the titles 'royal scribe', 'chief lector priest of the lord of the two lands', 'chamberlain of $\breve{S} w$ and Tfnwt', in addition to 'treasurer of the king of Lower Egypt', 'sole friend', and 'sm priest'. ${ }^{160}$ The doorkeeper of a temple iry-?3 $n h w t$-ntr could be a person of high rank. An example is highlighted by the text on a stela from Edfou, ${ }^{161}$ where a temple doorkeeper is designated as 'doorkeeper of the temple and priest $w^{c} b$ '. ${ }^{163}$ Following the Middle Kingdom, placing statues in temples was a privilege granted by royal favour, only acquired by governors and high priests. ${ }^{164}$ Clère $^{165}$ came to the conclusion that Min $\mathrm{ms}$ should have been designated by the title iry- 3 , but was not professionally a doorkeeper. It was rather his statue that should have been intended to act as doorkeeper of the temple. The situation is conversely different with $P \hat{i} 3 y$ as he held the title $s \underline{d} m-\ulcorner\breve{s}$ 'servant', and should have acted as porter. Another statue of Pi3y (Louvre E 124) that may also be dated to Ramsses II, ${ }^{166}$ bears the inscription identifying him as iry $3 \mathrm{~m}$ pr-nsw 'doorkeeper of the palace'.

These examples confirm that not all statues bearing the title iry-?3 $n$ hwt-ntr 'temple doorkeeper' functioned as doorkeepers. It is noteworthy that the above discussed examples of block statues are further completely different in function than the doorkeepers pictured in tomb scenes. The latter acted as real guards to the entrances in palace interiors and store rooms. Besides, unlike palatial contexts, doorkeepers of the temples were never depicted in representations. ${ }^{167}$ A thorough investigation of block statues bearing the title iry-? 3 is therefore anticipated for future research.

\section{Types of guard posts}

The doorkeeper was evidently responsible of guarding and protecting an area of which the entrance was closed or walled. The function of the guard posts was to keep watching the people entering or coming out of a place. ${ }^{168}$ Varied types of buildings

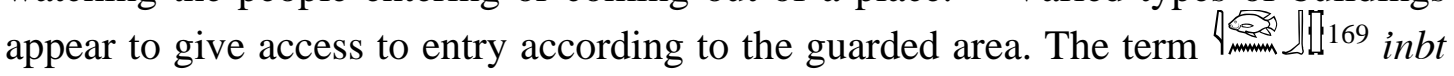

\footnotetext{
${ }^{160}$ Helck, W., Zur Verwaltung des Mittleren und Neuen Reichs, PdÄ 3 (Leiden, 1958), 454-5.

161 The stela which is actually in Cairo belongs to a man who served under Ahmos until Thutmosis I. Urk. IV, 29.

${ }^{162}$ Urk. IV, 30, 6.

${ }^{163}$ Clère, "Deux statues 'gardiennes de porte", 142.

164 Sourouzian, H., “Tempelstatuen”, in W. Helck and E. Otto (eds.), L̈̈ VI (Wiesbaden, 1986), 411, 412.

${ }^{165}$ Clère, "Deux statues 'gardiennes de porte", 143, 145.

166 Ouda, A. M., "The statue of 'The Doorkeeper of the Palace' Pỉy (Louvre E 124)", SAK 44 (2015), 294.

167 An example is the representation of the temple of Aton in the tomb of ITh-ms at Amarna. Davies, The Rock Tombs of El Amarna. Part 3, pl. XXX.

${ }^{168}$ Ventura, Living in a city of the dead, 135.

${ }^{169} \mathrm{~Wb}$ I, 94, 15, 16; 95, 1-3.
} 
should refer to the royal necropolis guard posts. 170 绾 translated 'fortification, fort, guard house'. ${ }^{171}$ In this respect distinctions should be made between fortified walls and watch posts.

As 'the tomb' difficult to confirm whether the same applied to the royal tomb entrance. However, it can be assumed that providing guards to secure a place depended on the nature of the guarded area. Kinds of buildings might have been varying in type and shape (i.e. fortress like, station, hut, etc.). There should have been a guarded defensive and inspection station or watch post; supposedly even five as per the interpretation of $t 35$ inbt. ${ }^{172}$ The latter were interpreted as being possibly series of small forts or guardhouses that topographically had to be passed in sequence by anyone following the route to or from the tombs of the kings. ${ }^{173}$ Most likely such stations might be assimilated to guarded inspection points, the function of which was to secure the passage along the valley leading to the royal tombs. ${ }^{174}$

\section{The doorkeeper's workplace}

The texts provide very little information as to the doorkeeper's location. ${ }^{175}$ Tomb iconography is not much telling either, and we do not know whether the doorkeeper only worked in the place or lived in it. The question arises whether the doorkeeper was a watchman based at a specific place. The only sources of information available are the New Kingdom attested representations. However, whether doorkeepers remained close to the gateway, or they were allowed inside, remains hypothetical.

By whom were they employed seems also a question worth investigating. The iryw-? of the tomb were employed by the regional administration. ${ }^{176}$ Whether or not the doorkeeper was the proprietor of his own $\square \square s_{t}$ 'house, room', ${ }^{177}$ also 'workplace' 178 where he could stay and sleep, ${ }^{179}$ remains improbable. The structure called ' $t$; being a building outside the village proper, ${ }^{180}$ and ${ }^{\prime} t$ iry ${ }^{\prime} 3$ 'the room of the

\footnotetext{
${ }^{170}$ Ventura, Living in a city of the dead, 142.

${ }^{171}$ Lesko, L. H.; Switalski-Lesko, B., A Dictionary of Late Egyptian, Volume I, 2nd ed. (Providence, 2002), 38. See Edgerton, W. F., “The strikes in Ramsses III's twenty-ninth year”, JNES 10, 3 (1951), 139 , n. 10 .

172 Ventura, Living in a city of the dead, 126, 138.

173 Ventura, Living in a city of the dead, 126, 138. However, the specific area in which $t 35$ inbt was located has not been agreed upon. See Ventura, Living in a city of the dead, 128, 129.

174 Ventura, Living in a city of the dead, 107, 126.

175 Goecke-Bauer, “Untersuchungen zu den 'Torwächtern' von Deir el Medine”, 134.

176 Ventura, Living in a city of the dead, 113.

${ }^{177}$ Lesko; Switalski-Lesko, A Dictionary of Late Egyptian I, 67.

${ }^{178}$ For the functional meaning of the word ' $t$, see Demarée, R. J., "A House is not a Home", in A. Dorn and T. Hofmann (eds.), Living and Writing at Deir el-Medine: Socio-historical embodiment of Deir elMedine texts, AH 19 (Basel, 2006), 66.

179 Demarée, "A House is not a Home", 65.

${ }^{180}$ Demarée, "A House is not a Home", 65.
} 
doorkeeper' were mentioned in descriptions of royal tombs. ${ }^{181}$ Černy mentioned 't iryw ' 3 'booths of the iryw ' 3 ' of the Valley of the Kings. ${ }^{182}$

In attested New Kingdom representations, the doorkeeper is never shown in a specific station or booth. He was rather depicted outside the entrance to the place he was supposed to keep guarding. It may be assumed that the doorkeeper should have been living either in close proximity to the place he was supposed to guard or in the same place.

It is not possible to determine with certainty whether doorkeepers resided in the place before the reign of Ramsses XI. ${ }^{183}$ However, in Deir el-Medineh doorkeepers were considered among the personnel of the outside or the 'exteriors' in O. Berlin K, $\mathrm{v}^{\mathrm{o}} 6$ 7; i.e. 'who do not live in the village'. ${ }^{184}$ The doorkeeper $h^{\complement}-m-w 3 s t$ was even reported accused of having entered the village proper without the permission of the guard. ${ }^{185}$

In papyrus Salt 124, dated to Sety II, Determining a specific place where seemingly doorkeepers were to be found was called $\int$ place of the doorkeepers'. This confirms the proposition of the presence of a doorkeepers' workplace. The text in the papyrus specifies the place of the doorkeepers as follows:

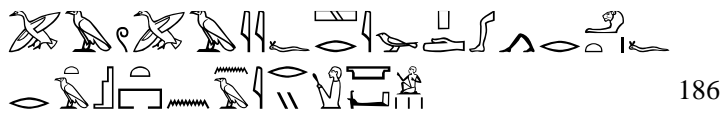

p3w p3y.f sri ${ }^{187}$ pd $^{188} r$ h ḩ3t.f

$r$ t3 st nn $n 3$ iryw- 3

His son ran away from him

to the place of the doorkeepers. ${ }^{189}$

\section{Ranking the doorkeeper's position}

The position of the doorkeeper seems to have been basically a male occupation. Very rare instances of female guards are known. ${ }^{190}$ In tomb representations, parts of the

181 Černy, J., The Valley of the Kings : fragments d'un manuscript inachevé, BdE 61 (Cairo, 1973), 28

f.; Demarée, "A House is not a Home", 64.

182 Černy, The Valley of the Kings, 28, 29, n.1.

183 Valbelle, D., Les ouvriers de la tombe : Deir El-Médineh à l'époque ramesside, BdE 96 (Cairo, 1985), 126.

${ }^{184}$ Valbelle, Les ouvriers de la tombe, 126.

${ }^{185}$ Ventura, Living in a city of the dead, 96.

186 Černy, J., "Papyrus Salt 124 (Brit. Mus. 10055)", JEA XV (1929), pl. XLIII; Sauneron, S., Textes et langages de l'Egypte pharaonique: cent cinquante années de recherches, 1822-1972: hommage à Jean-François Champollion, Volume III, Bde 64 (Cairo, 1974), pl. 8, recto.

${ }^{187} \mathrm{~Wb}$ IV, 525, (12). The phrase following $p 3 w$ is in apposition to the demonstrative pronoun. See Černy, "Papyrus Salt 124 (Brit. Mus. 10055)", 248, n. 26.

${ }^{188} \mathrm{~Wb}$ I, 501, (5), 566.

189 Černy, "Papyrus Salt 124 (Brit. Mus. 10055)", 245.

${ }^{190}$ Roth, A. M., A cemetery of palace attendants: Including G 2048-2099, G 2230+2231, and G 2240. Based upon the recording of the Harvard University-Museum of Fine Arts, Giza Matabas 6 (Boston, 1995), 151, fig. 80. 
harem were depicted separated by a door from other palace areas. This precaution was elucidated by the presence of male doorkeepers outside the doors. ${ }^{191}$

As for the status of the doorkeeper of the tomb, in O. IFAO 351, 2 he followed the gardener and the wood-cutter and preceded the potter and water-carrier. ${ }^{192}$ In $\mathrm{O}$. Gardiner 249, 6 a doorkeeper was ranked below the water-carrier, gardener, fisherman and washerman, and above the gypsum-worker and the potter. ${ }^{193}$ Ventura highlighted the fact that the iryw-? 3 of $p 3 \mathrm{hr}$ or of $p_{3} \mathrm{htm}$ were almost illiterate, and had to operate according to what they were told to do. ${ }^{194}$

Ration lists from Deir el-Medine village recorded small payments received by the doorkeepers. ${ }^{195}$ Yet, Papyrus BM 10068 recorded that a doorkeeper and a chief doorkeeper possessed houses of their own. ${ }^{196}$

\section{Conclusion}

The nature of the doorkeepers' duties certainly varied according to the place to which they were attached, and also according to the concerned era. The definition of the institution to which the doorkeeper was attached is therefore of importance in interpretation. As for the $p r-n s w$ for example, the vizier manages the control of the doorways. ${ }^{197}$ Leprohon ${ }^{198}$ discussed the function of the who has entry' in temples.

It seems that such a profession was inherited as porters of the tombs in the community of Deir el-Medineh were often the guardian's sons. ${ }^{200}$ The title iry 3 m pr-nsw 'doorkeeper of the palace' was an administrative title that could be inherited by the son from his father. ${ }^{201}$

Admittance to some places was restricted, yet it is tempting to consider that mundane places would not have required access barring. However, the doorkeeper seems to have been the only barrier to access in all the cases. On the stela MMA 57.95:5 the overseer of the Labour Compound imy-r hnrt states that he was iry ' 3 hr ntt iwtt 'one who acted as a door for what is and what is not'. ${ }^{202}$ The person acting as iry ' 3 was associated with the doorkeeper whose tasks included observing people going into and

\footnotetext{
${ }^{191}$ E.g. Davies, The Rock tombs of El Amarna. Part 6, pl. 28, doorway.

192 Černy, A Community of workmen at Thebes in the Ramesside period, 170, n. 5 .

193 Černy, A Community of workmen at Thebes in the Ramesside period, 170, n. 6.

${ }^{194}$ Ventura, Living in a city of the dead, 115.

195 McDowell, A. G., Village Life in Ancient Egypt: laundry lists and love songs (Oxford, 1999), 54.

196 Černy, A Community of workmen at Thebes in the Ramesside period, 165, (vo. 1, 22, 23).

197 Van den Boorn, G.P.F., The Duties of the Vizier: Civil Administration in the Early New Kingdom (London, 1988), 74.

198 Leprohon, "Gatekeepers of This and the Other World", 77.

${ }^{199} \mathrm{~Wb}$ I, 283, 11.

200 Černy, A Community of workmen at Thebes in the Ramesside period, 168; Valbelle, Les ouvriers de la tombe, 126.

${ }^{201}$ Ouda, "The statue of 'The Doorkeeper of the Palace' Pi3y (Louvre E 124)", 284.

${ }^{202}$ Fischer, H. G., "The inscription of 'In-it.f, born of Tfi", JNES 19, 4 (1960), 265, n. [o]; Leprohon, "Gatekeepers of This and the Other World", 78.
} 
outside of the house, buying some commodities for the inhabitants, transporting goods to persons living outside the house and doing small reparations. ${ }^{203}$

Precautions were further taken in order not to leave the house without being guarded. ${ }^{204}$ The writer of O. Cairo 25670 asks a female friend or relative to leave Imn-m-wiz stay in his house so he can watch it. ${ }^{205}$

The studied scenes and texts allow more specifications to be added to the information known about doorkeepers. Unofficial documents proved to have been as informative as official ones. In comparison with the information provided by the texts, representations offer a wide spectrum allowing more details to be explained.

The doorkeeper was absent from representations during the Old and the Middle Kingdoms. The only existing three dimensional representations are the Middle Kingdom models encountered in the tomb of $M k t-R$. Whereas all the written sources concerning doorkeepers date to the Nineteenth and the Twentieth Dynasties, representational material mostly date to the Eighteenth and the Nineteenth Dynasties; mostly from the Amarna period. The representations depicting doorkeepers all date to the Eighteenth Dynasty, with only two examples dated to the Nineteenth Dynasty.

The occurrence of the motif merely in New Kingdom representations prompts several observations. Unlike other workers and artisans, the doorkeeper's work was in the palace interiors and store rooms which were not subject of depiction before the New Kingdom. The originality of the subject in the New Kingdom renders the doorkeeper's motif an interesting addition to the scene repertoire of daily life activities, this time within the palace.

As for the gestures, the doorkeeper's figures were depicted freely moving, not formalized in any way. The motif is one of the less frequently encountered figures, unconventionally depicted leaning with one leg at the wall behind. The figure did not follow specific seated or standing attitudes, nor was it stylized. The studied scenes allow to conclude that the number of doorkeepers operating in the palace interiors was variable (e.g. figs. 4, 5, 10, 13). In representations depicting the harem interiors every door was being guarded by a doorkeeper (figs. 13, 14a, 14b). The examples depicted are enlightening; the scenes showing the doorkeepers are all depicted in the interior areas.

The doorkeeper was shown in the scenes as an anonymous figure. He was depicted as a small-scaled genre motif; reflecting his duties and his social position. He was in all cases shown in front of, beside or behind the door. His main duty was to guard against unauthorized persons. In the representations concerning palatial contexts and storehouses, there are no guarded stations; rather merely a door marking the entrance where the doorkeeper was usually situated. Female guards were probably assigned to

203 Janssen, Jac. J., Village Varia: Ten Studies on the History and Administration of Deir-el-Medina, EgUit 11 (Leiden, 1997), 55; Goecke-Bauer, 'Untersuchungen zu den 'Torwächtern' von Deir el Medine", 142.

${ }^{204}$ McDowell, Village Life in Ancient Egypt, 66.

205 Allam, Sch., Hieratische Ostraca und Papyri aus der Ramessidenzeit, Urkunden zum Rechtsleben im Alten Ägypten I (Tübingen, 1973), 67, (34); McDowell, Village Life in Ancient Egypt, 66. 
guard the intimate parts of the royal harem. ${ }^{206}$ Nevertheless, they do not appear on tomb walls as their male counterparts.

When it comes to the definition of the functions and roles of a workman depending on the various details in pictorial representations, some information may be absent, but may be complemented by the texts. With regard to records on ostraca and papyri, it may be concluded that what the doorkeeper did was possibly just guarding the doorway or occasionally assisting other workmen. ${ }^{207}$

The stylistic analysis and artistic conventions adopted in picturing the doorkeeper's motif en miniature in both models and representations pinpoint his relatively modest role. It is a genre motif visually reflecting social settings par excellence. The position of the doorkeeper within the workmen community may be reconstructed by referring to several indices. His poses and attitudes do not point to a high ranked position. He sits on the floor, stands by the door, and just holds a stick or a type of brush for sweeping the floor, ${ }^{208}$ and only in a few cases, a palette. Besides, he bears no sorts of weapons, yet sometimes keeps a stick nearby.

The duties assigned to doorkeepers could therefore be detected to have been basically the following:

- to ensure watch posts

- to observe limited access

- to ward off undesirable persons

The figure of the doorkeeper remains a code of exceptional representations, unattested before the Amarna period. Bodily movement was deliberately depicted, and the skilfully represented motif enjoyed an obvious freedom in its representation, adding to its charm. The main characteristics of the doorkeepers' representations are the following:

- absence of formalised figures

- freedom of movement

- unrestricted gestures or attitudes

- unformal poses

Concerning their place of residence, it seems probable that doorkeepers remained inactive in their work places when they were freed from work instead of moving back to their houses. Such information should be taken into consideration when reconstructing the doorkeepers' functions related to their figured attitudes. An in depth study of the details makes us wonder whether the dormant representations of doorkeepers were napping while being work-free. Besides, the doorkeeper was occasionally shown angrily provoked by passersby. In the tomb of $N f r-h t p$ at Thebes

\footnotetext{
${ }^{206}$ Kanawati, N., “A Female Guard Buried in the Teti Cemetery”, BACE 12 (2001), 66, 67.

${ }^{207}$ Janssen, Village Varia, 55.

${ }^{208}$ It is noteworthy that the representation of $P 3-h r-n-h n s w$ is one of the cleared depictions of the brush held in his right hand. Guilhou, "Génies funéraires, croquet-mitaines ou anges gardiens ? Étude sur les fouets, balais, palmes et épis en guise de couteaux", 383, fig. 42 .
} 
the doorkeeper seems to be chasing away the children attending a garden party with the short stick. ${ }^{209}$

The representational material including the doorkeeper allow to confirm the information of access barring to the private areas of the royal palace or storage areas. The doorkeeper's presence conveys the information that some people were authorized to enter while others were banned from entry or unauthorized. The representations also allow to conclude that categories of persons that were allowed to have access were the following:

- specific designated officials

- the personnel or servants who were to perform their work

- specific invited guests

The reconstruction of the doorkeeper's duties enables to provide supporting evidence for the interpretation. In figurative documents the studied details highlight the role of the doorkeeper, in addition to the artistic conventions adopted in picturing the motif. Their postures and attitudes would rather be interpreted as aspects of realism, especially that most of the concerned representations date to the Amarna period. Interpreting the iconography and the interplay of motifs in the scenes enable a better understanding of the doorkeeper's role. The studied scenes studied provide conclusive evidence as to the reading of the entire compositions.

\section{Bibliography}

- Allam, Sch., Hieratische Ostraca und Papyri aus der Ramessidenzeit, Urkunden zum Rechtsleben im Alten Ägypten I (Tübingen, 1973).

- Van den Boorn, G.P.F., The Duties of the Vizier: Civil Administration in the Early New Kingdom (London, 1988).

- Černy, J., "Papyrus Salt 124 (Brit. Mus. 10055)", JEA XV (1929), 243-258.

- Černy, J., The Valley of the Kings : fragments d'un manuscript inachevé, BdE 61 (Cairo, 1973).

- Černy, J., A Community of workmen at Thebes in the Ramesside period, BdE 50, 3rd edition (Cairo, 2004).

- Champollion le Jeune, Monuments de l'Égypte et de la Nubie: notices descriptives conformes aux manuscrits autographes rédigés sur les lieux I (Paris, 1929).

- Clère, J. J., "Deux statues 'gardiennes de porte”, JEA 54 (1968), 135-148.

- Davies, N. de G., The Rock tombs of El Amarna. Part 1: The Tomb of Meryra, ASEg 13 (London, 1903).

- Davies, N. de G., The Rock tombs of El Amarna. Part 2: Tombs of Panehesy and Meryra II, ASEg 14 (London, 1905).

- Davies, N. de G., The Rock Tombs of El Amarna. Part 3: The Tombs of Huya and Ahmes, ASEg 15 (London, 1905).

- Davies, N. de G., The Rock Tombs of El Amarna. Part 4: The Tombs of Penthu, Mahu, and others, ASEg 16 (London, 1906).

- Davies, N. de G., The Rock tombs of El Amarna. Part 6: Tombs of Parennefer, Tutu and $A \ddot{y}$, ASEg 18 (London, 1908).

${ }^{209}$ Davies, The tomb of Nefer-hotep at Thebes I, 25. 
- Davies, N. de G., The tomb of Nefer-hotep at Thebes, Volume I, MMAEE 9 (New York, 1933).

- Davies, N. de G., The tomb of Nefer-hotep at Thebes, Volume II, MMAEE 9 (New York, 1933).

- Demarée, R. J., "A House is not a Home", in A. Dorn and T. Hofmann (eds.), Living and Writing at Deir el-Medine: Socio-historical embodiment of Deir el-Medine texts, AH 19 (Basel, 2006).

- Edgerton, W. F., “The strikes in Ramsses III's twenty-ninth year”, JNES 10, 3 (1951),137145.

- Erman, A., Neuaegyptische Grammatik (Leipzig, 1880).

- Erman, A.; Grapow, H., Wörterbuch der Ägyptischen Sprache, 6 vols (Berlin, 1961-71). (cited as $W b$ )

- Faulkner, R. O., A Concise Dictionary of Middle Egyptian (Oxford, 1988).

- Felgenhauer, A., Aus Gräbern, Heiligtümern und Siedlungen: Die altägyptische Sammlung des Übersee-Museums Bremen (Darmstadt, 2015).

- Fischer, H. G., "The inscription of 'In-it.f, born of Tfi”, JNES 19, 4 (1960), 258-268.

- Gardiner, A., Egyptian Grammar, Third edition (London, 1957).

- Ghalioungui, P., "Sur deux formes dobésité représentées dans l'Égypte ancienne”, ASAE 49 (1949), 303-316.

- Goecke-Bauer, M., “Untersuchungen zu den 'Torwächtern' von Deir el Medine”, in: Jac. J. Janssen (ed.), Woodcutters, potters and doorkeepers. Service personnel of the Deir elMedina workmen, EgUit 17 (Leiden, 2003).

- Grandet, P., Catalogue des ostraca hiératiques non littéraires de Deîr el-Médînéh, Tome VIII, $n^{o s}$ 706-830, DFIFAO 39 (Cairo, 2000).

- Grandet, P., Catalogue des ostraca hiératiques non littéraires de Deîr el-Médinéh, Tome IX. Nos 831-1000, DFIFAO 41 (Cairo, 2003).

- Guglielmi, W., Reden, Rufe und Lieder auf altägyptischen Darstellungen der Landwirtschaft, Viehzucht, des Fisch- und Vogelfangs vom Mittleren Reich bis zur Spätzeit, TÄB 1 (Bonn, 1973).

- Guilhou, N., "Génies funéraires, croquet-mitaines ou anges gardiens ? Étude sur les fouets, balais, palmes et épis en guise de couteaux", in S. H. Aufrère, Encyclopédie religieuse de l'Univers végétal - Croyances phytoreligieuses de l'Égypte ancienne I, Orientalia Monspeliensia X (Montpellier, 1999), 365-417.

- Gutgesell, M., Die Datierung der Ostraka und Papyri aus Deir el-Medineh und ihre ökonomische Interpretation. Teil I. Die 20. Dynastie, HÄB 18-19 (Hildesheim, 1983).

- Hannig, R., Ägyptisches Wörterbuch II: Mittleres Reich und Zweite Zwischenzeit I, Kulturgeschichte der Antiken Welt 112 (Mainz am Rhein, 2006).

- Helck, W., "Türhüter”, in W. Helck and E. Otto (eds.), LÄ VI (Wiesbaden, 1986), 787788.

- Helck, W., Zur Verwaltung des Mittleren und Neuen Reichs, PdÄ 3 (Leiden, 1958).

- Houlihan, P. F., Wit \& humour in ancient Egypt (London, 2001).

- Janssen, Jac. J., Commodity prices from the Pamesside Period: An economic study of the village of necropolis workmen at Thebes (Leiden, 1975).

- Janssen, Jac. J., “Two personalities", in R. J. Demarée and Jac. J. Janssen (eds.), Gleanings from Deir El-Medîna, EgUit 1 (Leiden, 1982).

- Janssen, Jac. J., Village Varia: Ten Studies on the History and Administration of Deir-elMedina, EgUit 11 (Leiden, 1997). 
- Jones, D., An Index of Ancient Egyptian Titles, Epithets and Phrases of the Old Kingdom I, BAR 866 (I) (Oxford, 2000).

- Kanawati, N., "A Female Guard Buried in the Teti Cemetery", BACE 12 (2001), 65-70.

- Kemp, B., The City of Akhenaton and Nefertiti: Amarna and its people (Cairo, 2012).

- Leprohon, R. J., "Gatekeepers of This and the Other World", JSSEA XXIV (1994), 77-91.

- Lesko, L. H.; Switalski-Lesko, B., A Dictionary of Late Egyptian, Volume I, 2nd ed. (Providence, 2002).

- Linköping 189: 5000 år Egypt. konst (Nationalmuseum Stockholm).

- Martin, G. T., Corpus of Reliefs of the New Kingdom from the Memphite Necropolis and lower Egypt (London, 1987).

- Massart, A., "The Egyptian Geneva Papyrus MAH 15274”, MDAIK 15 (1957), 172-185.

- Meeks, D., Année Lexicographique Égypte ancienne, Volume I (Paris, 1980). (cited as AnLex I)

- Meeks, D., Année Lexicographique Égypte ancienne, Volume III (Paris, 1982). (cited as AnLex III)

- McDowell, A. G., Village Life in Ancient Egypt: laundry lists and love songs (Oxford, 1999).

- Morenz, L. D., Kleine Archäologie des ägyptischen Humors: Ein Kulturgeschichtlicher Testschnitt, B̈̈B 3 (Berlin, 2013).

- Naville, E., Das ägyptische Todtenbuch der XVIII. Bis XX. Dynastie (Berlin, 1886).

- Ouda, A. M., "The statue of 'The Doorkeeper of the Palace' Pi3y (Louvre E 124)", SAK 44, 2015, 283-295.

- Ramond, P., "Un socle pour une statuette de Thot", JEA 65 (1979), 170-171.

- Roth, A. M., A cemetery of palace attendants: Including G 2048-2099, G 2230+2231, and $G$ 2240. Based upon the recording of the Harvard University-Museum of Fine Arts, Giza Matabas 6 (Boston, 1995).

- Säve-Söderbergh, T., Four eighteenth Dynasty tombs, Private Tombs at Thebes I (Oxford, 1957).

- Sauneron, S., Textes et langages de l'Egypte pharaonique: cent cinquante années de recherches, 1822-1972: hommage à Jean-François Champollion, Volume III, Bde 64 (Cairo, 1974).

- Sethe, K. H., Urkunden der 18. Dynastie. IV. Historisch-biographische Urkunden (Leipzig, 1909). (cited as Urk. IV)

- Sourouzian, H., "Tempelstatuen", in W. Helck and E. Otto (eds.), L̈̈ VI (Wiesbaden, 1986), 411-414.

- Sweeney, D., Correspondence and Dialogue: Pragmatic Factors in Late Ramesside Letter-Writing, ÄAT 49 (Wiesbaden, 2001).

- Valbelle, D., Les ouvriers de la tombe : Deir El-Médineh à l'époque ramesside, BdE 96 (Cairo, 1985).

- Ventura, R., Living in a city of the dead: A selection of topographical and administrative terms in the documents of the Theban necropolis, OBO 69 (Freiburg, 1986).

- Volokhine, Y., La frontalité dans l'iconographie de l'Égypte ancienne, CSEG 6 (Geneva, 2000).

- Van de Walle, B., L'humour dans la littérature et dans l'art de l'ancienne Égypte, Scholae Adriani de Buck memoriae dicatae IV (Leiden, 1969).

- Ward, W. A., Index of Egyptian Administrative and Religious Titles of the Middle Kingdom (Beirut, 1982). 
- Wilkinson, J., The manners and customs of the ancient Egyptians, ed. Birch, Volume I (London, 1878).

- Winlock, H. E., Models of Daily Life in Ancient Egypt from the Tomb of Meket-Ré $\bar{e}^{\varsigma}$ at Thebes (New York, 1955).

- Wreszinski, W., Atlas zur altägyptischen Kulturgeschichte, Volume I (Leipzig, 1923).

- Wreszinski, W., Atlas zur altägyptischen Kulturgeschichte, Teil III: Gräber des Alten Reiches (bearbeitet von H. Schäfer) (Leipzig, 1936).
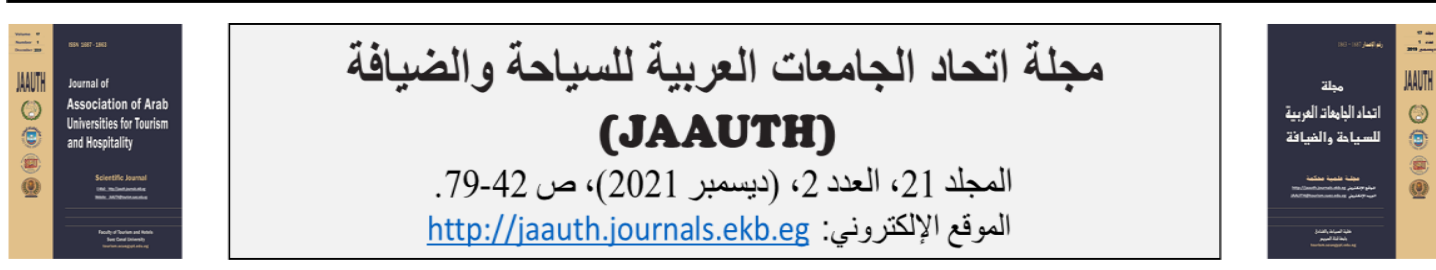

\section{تداخل العناصر التى تعكس مهام حارس البوابة}

\section{الشكل والوظيفة \\ رانيا يونس مرزبان}

الأستاذ المساعد بقسم الإرشاد السياحي، كلية السياحة والفنادق، جامعة الإسكندرية

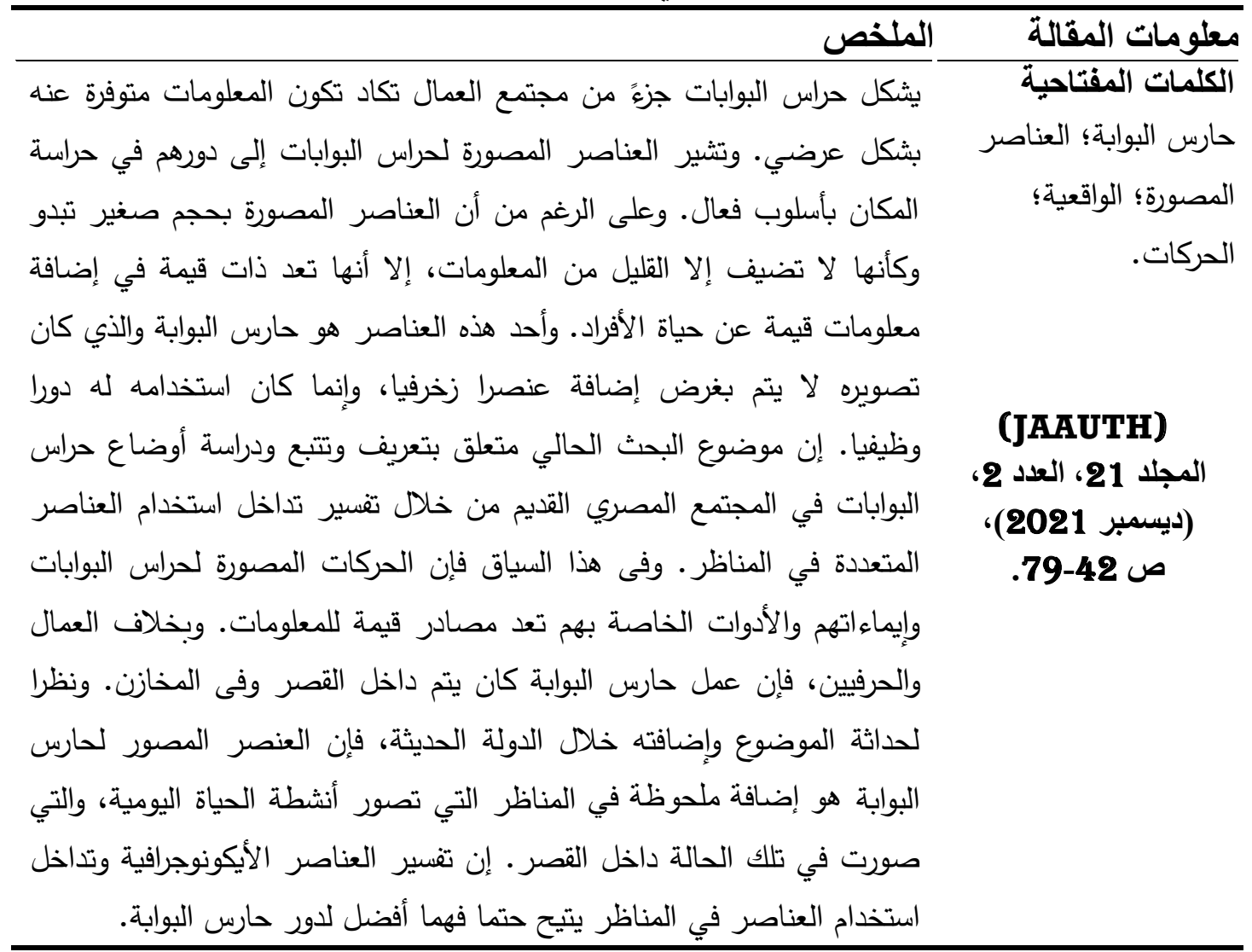

